\title{
TRYPTOPHAN DENDRIMERS THAT INHIBIT \\ HIV REPLICATION, PREVENT VIRUS ENTRY AND BIND \\ TO THE HIV ENVELOPE GLYCOPROTEINS GP120 AND GP41
}

Eva Rivero-Buceta, ${ }^{1}$ Elisa G. Doyagüez, ${ }^{1,2}$ Ignacio Colomer, ${ }^{1,3}$ Ernesto Quesada,,${ }^{1}$ Leen Mathys, ${ }^{4}$ Sam Noppen, ${ }^{4}$ Sandra Liekens, ${ }^{4}$ María-José Camarasa, ${ }^{1}$ María-Jesús Pérez-Pérez, ${ }^{1}$ Jan Balzarini, ${ }^{4}$ Ana San-Félix* ${ }^{1}$

${ }^{1}$ Instituto de Química Médica (IQM-CSIC), Juan de la Cierva 3, 28006 Madrid

2 'Present adress': Centro de Química Orgánica "Lora-Tamayo" (CSIC), Juan de la Cierva 3, 28006 Madrid

3 'Present adress': Department of Chemistry, University of Oxford, Chemistry Research Laboratory, 12 Mansfield Road, Oxford OX1 3TA, UK

${ }^{4}$ Rega Institute for Medical Research, KU Leuven, B-3000 Leuven, Belgium

\begin{abstract}
Dendrimers containing from 9 to 18 tryptophan residues at the peryphery have been efficiently synthesized and tested against HIV replication. These compounds inhibit an early step of the replicative cycle of HIV, presumably virus entry into its target cell. Our data suggest that HIV inhibition can be achieved by the preferred interaction of the compounds herein described with glycoproteins gp120 and gp41 of the HIV envelope preventing interaction between HIV and the (co)receptors present on the host cells. The results obtained so far indicate that 9 tryptophan residues on the periphery are sufficient for efficient gp120/gp41 binding and anti-HIV activity.
\end{abstract}

Keywords: Antiviral agents, AIDS, HIV, tryptophan

Corresponding author:

Instituto de Química Médica (CSIC), Juan de la Cierva 3, 28006 Madrid

Telephone: 3491 2587617; Fax: 34915644853

E-mail: anarosa@iqm.csic.es

\section{Introduction}

AIDS still remains one of the leading infectious diseases for which there is no curative treatment and no vaccine [1]. Current antiretroviral therapy against the human immunodeficiency virus (HIV), the etiological agent of AIDS, consists of 26 clinically approved drugs, primarily focused on the viral enzymes protease and reverse transcriptase, which are administrated in combination in the so-called Highly Active AntiRetroviral Therapy (HAART) [2]. HAART modalities have been improved and extend the lives of patients infected with HIV. However, despite this major therapeutic success, the combination regimen is associated with long-term side-effects and the emergence of drug-resistant HIV strains [3]. Therefore, there is a need for the development of improved drugs targeting events in the HIV-1 replication cycle other than those catalyzed by protease and reverse transcriptase enzymes [4]. In this respect, HIV inhibitors able to block viral fusion/entry are particularly attractive [5]. To date, only two drugs among this category have been approved by the FDA, enfuvirtide (T20) [6], a 36-amino acid peptide that binds viral glycoprotein gp41, and maraviroc [7], a small molecule CCR5-antagonist. Therefore entry/fusion inhibitors represent a promising and still unexploited area of research.

Relative to the other classes of antiretroviral drugs (i.e. reverse transcriptase, protease and integrase inhibitors), which act once the cells have been alredy infected by HIV, fusion/entry inhibitors have the advantage of blocking de novo cell infection, preventing the uptake of the virus by the uninfected CD4-positive cells and therefore the spread of infection [8]. In addition, because their mechanism of action is different from the existing antiretroviral drugs, entry/fusion inhibitors would show full efficacy against viruses resistant to the existing anti-HIV inhibitors. Moreover, acting outside the cellular environment represents an additional advantage of this class of anti-retroviral drugs.

The entry of HIV into its target cells is a multistep time-ordered process involving multiple sequential interactions between the viral envelope glycoproteins (gp120 and gp41) and host cell surface proteins (CD4, CCR5 or CXCR4). It may be divided into three distinct steps: (i) attachment of the viral gp120 to the CD4 T cell receptor, (ii) binding of the gp120 to the host cell 
co-receptors (CCR5 or CXCR4) and (iii) fusion of the viral and cellular membranes [5d]. All these three steps have been considered for drug design of HIV-1 entry inhibitors [9]. However, as it was proposed by Teixeira et al [9a], it might be preferable to develop anti-HIV drugs targeting viral proteins (gp120 and gp41) rather than host cell molecules (CD4, CCR5 and CXCR4), because binding these host cellular molecules might interfere with their normal functions, causing toxic or adverse effects. Despite this, reports about entry inhibitors with HIV activity associated to gp120 and gp41 binding are still scarce [10].

We have previously reported [11] that triazine derivatives containing 6 Tryptophan (Trp) amino acids, exemplified by compound I (Figure 1), inhibit HIV infection at an early stage of the replicative cycle, presumably by interaction with the viral glycoproteins gp 120 and gp41. We have now undertaken the synthesis and anti-HIV evaluation of a series of Trp dendrimers easily constructed by combining a core structure of $3,4,5$ or 6 carboxylic acids with an aminotriester as a branching unit that facilitates the incorporation of up to 18 Trp on the periphery.

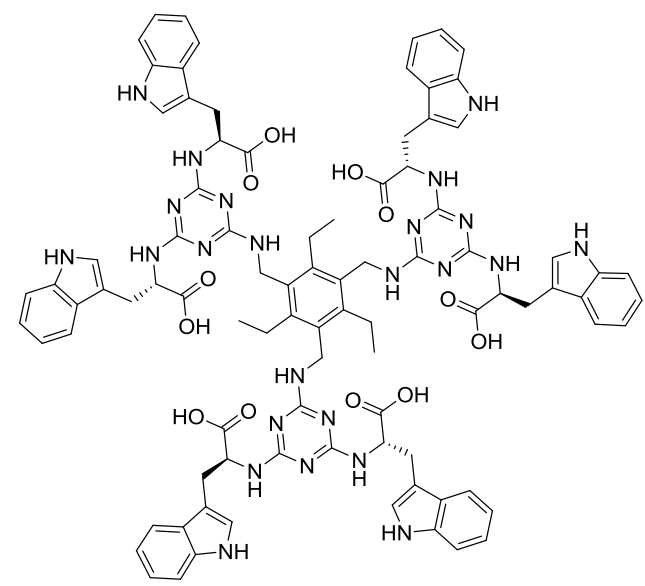

I

Fig. 1

\section{Results and discussion}

\subsection{Chemical results}

Firstly, dendrimers with 9 tryptophans on the periphery were obtained. For the synthesis of these compounds the commercially available aminotriester 1 (Behera's amine) [12] was used as spacer arm and tri- carboxylic acids, a-d, with different conformational flexibility, as scaffolds (Scheme 1). Carboxylic acid a, the same used in the previously described triazine derivative I, was obtained following literature procedure [13], while carboxylic acids b-d were commercially available. Reaction of these carboxylic acids a-d with aminotriester 1[12] in the presence of HATU/DIPEA and subsequent deprotection of the tert-butyl protected intermediates 2a-d, afforded compounds 3a-d (nude acids), containing nine carboxylic acids on the periphery (Scheme 1). These compounds were easily isolated in almost quantitative yield by precipitation with ethyl acetatemethanol. 

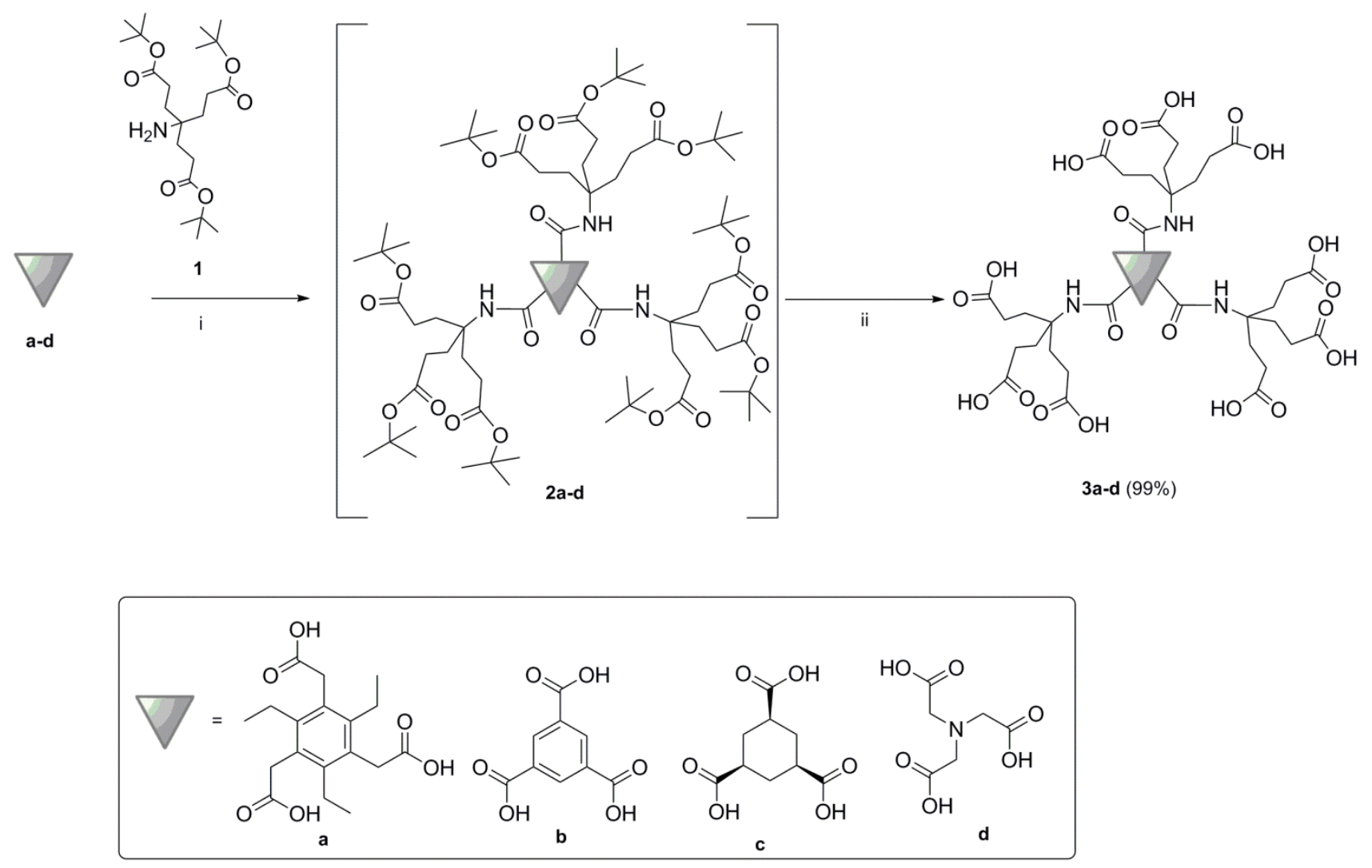

\section{Scheme 1}

Coupling of nonaacids 3a and 3d [14] with $\mathrm{H}-\mathrm{Trp}-\mathrm{OMe} \cdot \mathrm{HCl}$ in the presence of HATU and DIPEA gave compounds 4a (36\%) and $\mathbf{4 d}(82 \%)$, while reaction of nonaacids, 3b [15] and 3c, with $\mathrm{H}-\mathrm{Trp}-\mathrm{OBn} \cdot \mathrm{HCl}$ afforded $\mathbf{4 b}(94 \%)$ and $\mathbf{4 c}(86 \%)$ (Scheme 2). Methyl ester deprotection of $\mathbf{4 a}$ and $\mathbf{4 d}$, under basic conditions $\left(\mathrm{LiOH} / \mathrm{H}_{2} \mathrm{O}\right)$, followed by acidification at $\mathrm{pH}=2$ and purification of the crude product by reverse phase chromatography afforded compounds 5a and 5d in $43 \%$ and $49 \%$ yields respectively (Scheme 2). On the other hand, $\mathbf{4 b}$ and $\mathbf{4 c}$ were debenzylated by catalytic hydrogenation $\left(\mathrm{H}_{2}, 10 \% \mathrm{Pd}-\mathrm{C}\right)$ to give $\mathbf{5 b}$ and $\mathbf{5 c}$ in 20 and $25 \%$ yields respectively (Scheme 2). 


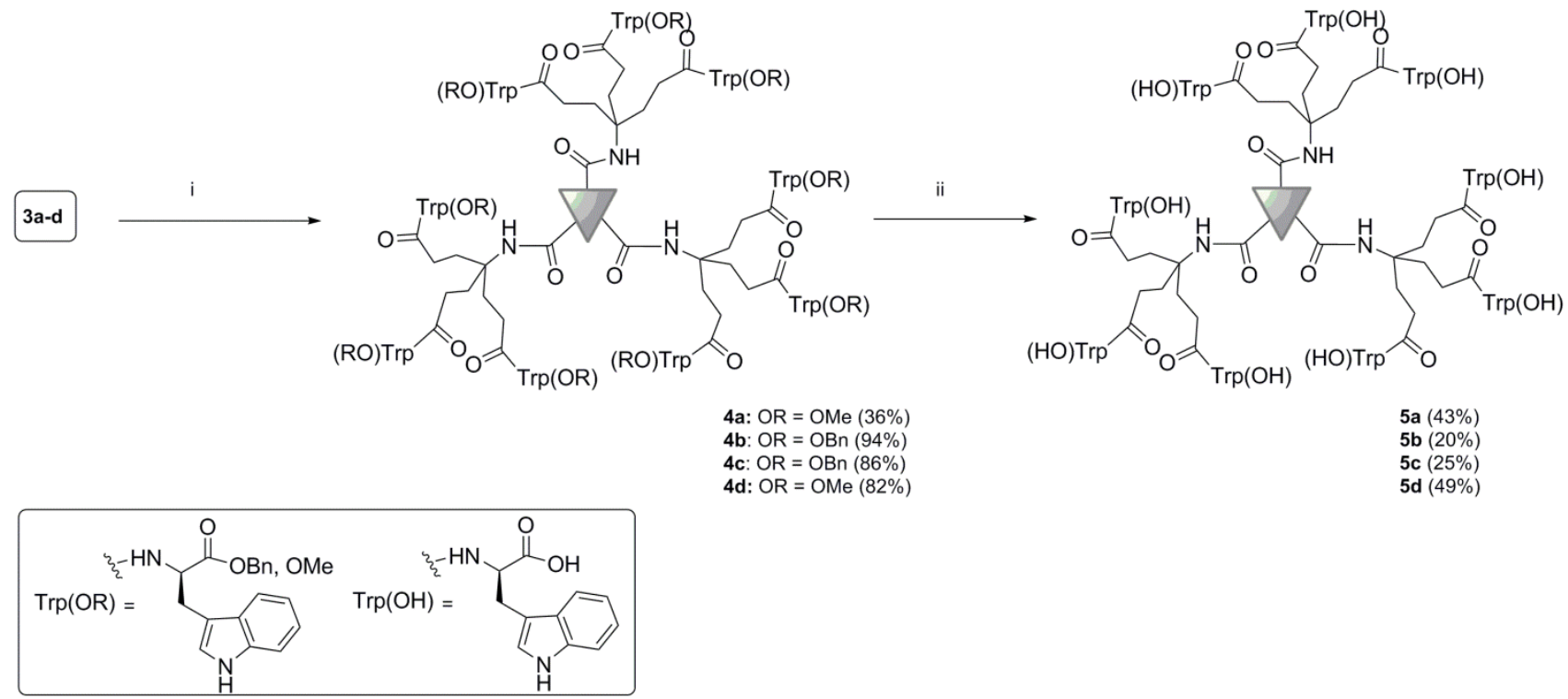

Scheme 2

Synthesis of compounds containing 12,15 and 18 Trps on the periphery was performed using a strategy similar to those described earlier for compounds with 9 tryptophans. In this case, functionalized compounds (e-g), with 4, 5 and 6 carboxylic acids as attachment points, were used as central scaffolds. Reaction of these compounds with aminotriester 1[12] in the presence of HATU and DIPEA afforded the tert-butyl derivatives 2e-g. Subsequent acidic deprotection and precipitation using ethyl acetate/methanol gave carboxylic acids $\mathbf{3 e - g}$ in $80-88 \%$ yields (Scheme 3 ).
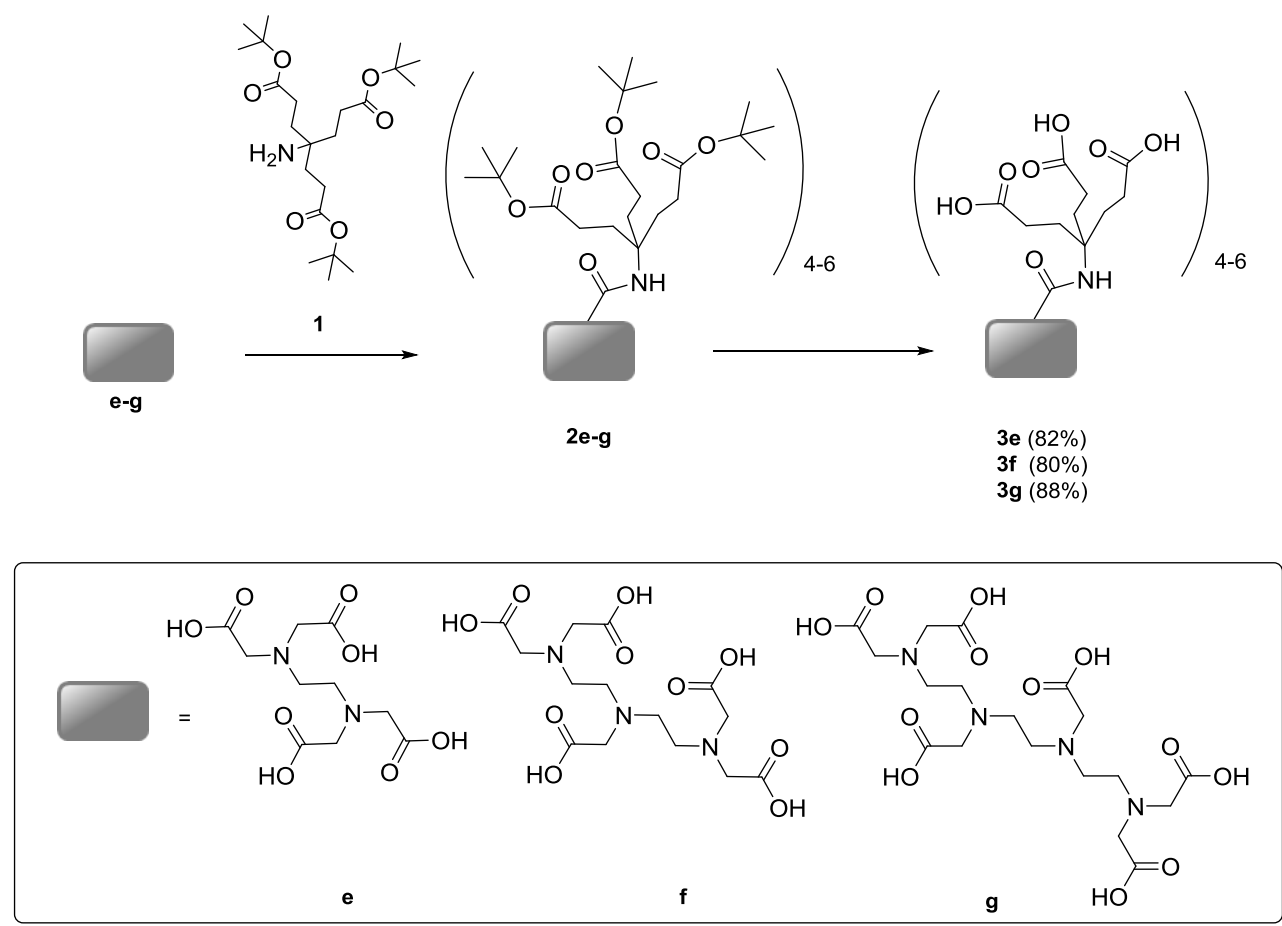

\section{Scheme 3}


Reaction of carboxylic acid 3e with $\mathrm{H}-\mathrm{Trp}-\mathrm{OBn} \cdot \mathrm{HCl}$ in the presence of HATU and DIPEA gave compound 4e (61\%) that was subsequently debenzylated by catalytic hydrogenation $\left(\mathrm{H}_{2}, 10 \% \mathrm{Pd}-\mathrm{C}\right)$ to give $\mathbf{5 e}$ in $38 \%$ yield (Scheme 4). Alternatively, reaction of $\mathbf{3 f}$ and $\mathbf{3 g}$ with $\mathrm{H}-\mathrm{Trp}-\mathrm{OMe} \cdot \mathrm{HCl}$ in the presence of HATU and DIPEA gave compounds $\mathbf{4 f}$ and $\mathbf{4 g}$. Methyl ester deprotection as described above $\left(\mathrm{LiOH} / \mathrm{H}_{2} \mathrm{O}\right)$ and purification of the crude material by reverse phase chromatography gave the desired compounds $\mathbf{5 f}$ and $\mathbf{5 g}$ in $24 \%$ and $78 \%$ yields, respectively (Scheme 4).
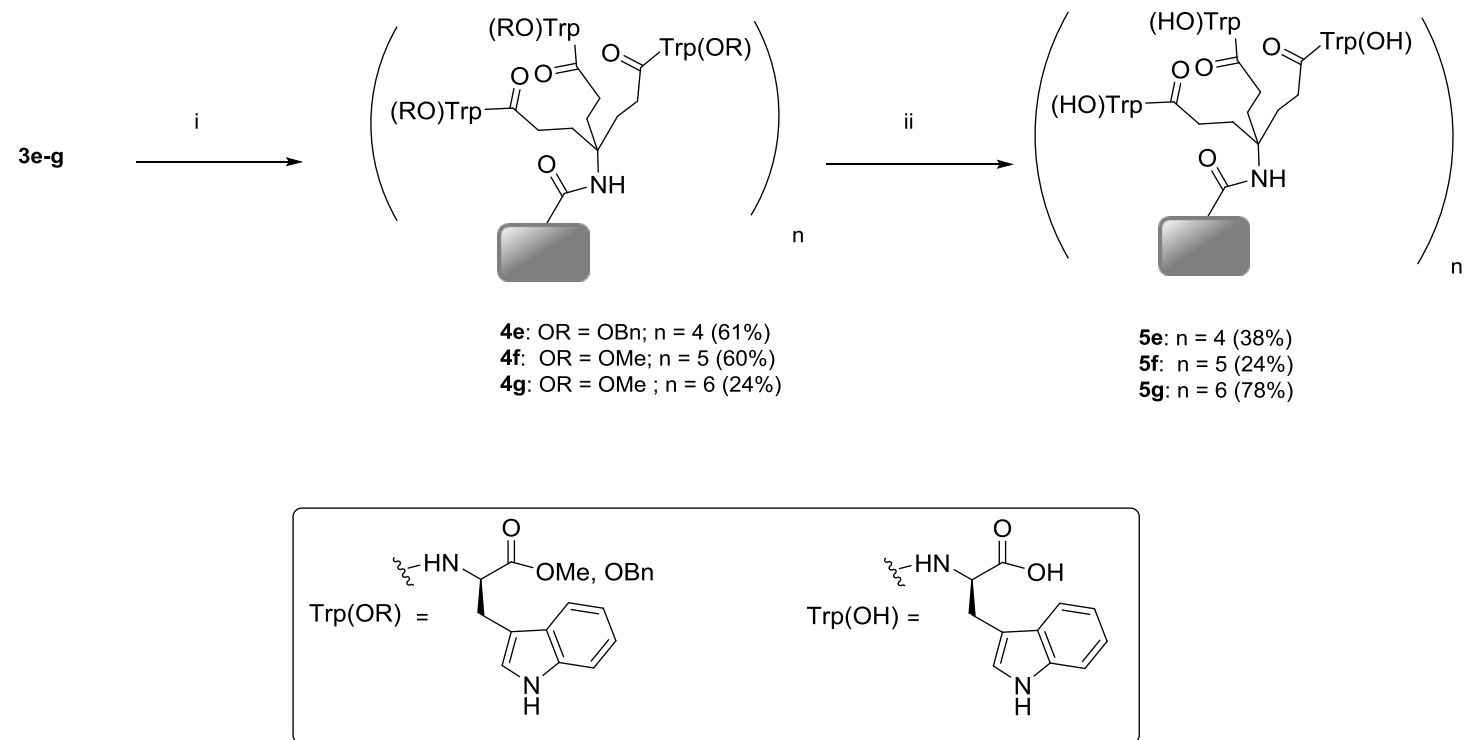

\section{Scheme 4}

Finally, nitrodendron 8 with 9 tryptophans on the periphery, was prepared by reaction of dendron 6 [16] with H-Trp$\mathrm{OMe} \cdot \mathrm{HCl}$ in the presence of HATU/DIPEA, followed by methyl ester deprotection $\left(\mathrm{LiOH} . \mathrm{H}_{2} \mathrm{O}\right)$ and purification of the crude product by reverse phase chromatography (Scheme 5).
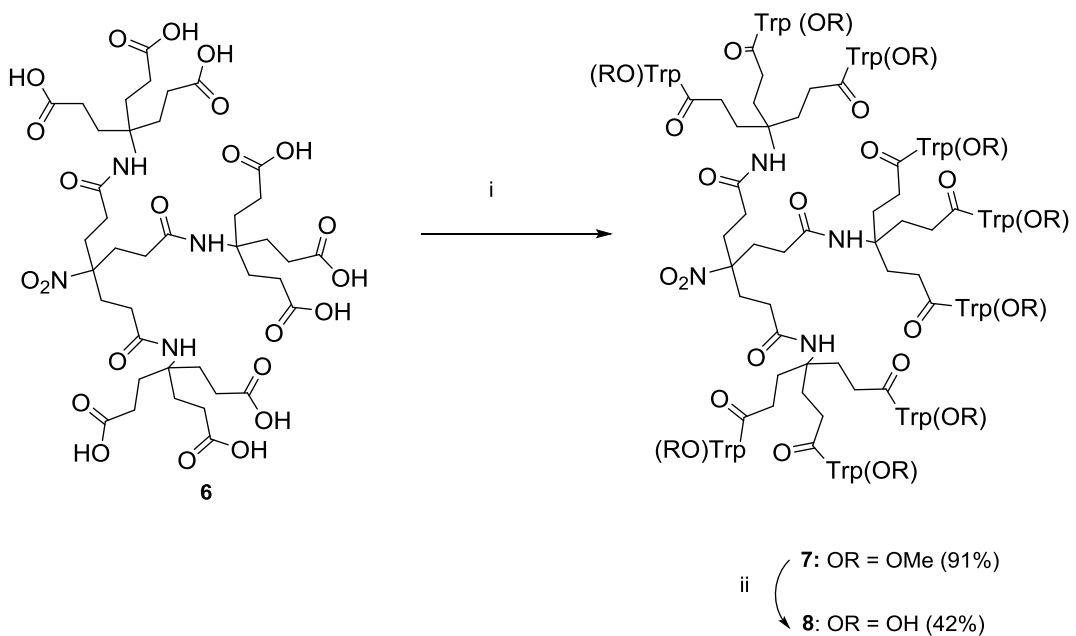

\section{Scheme 5}

The characterization of these compounds was performed by ${ }^{1} \mathrm{H}$ and ${ }^{13} \mathrm{C}$ NMR spectroscopies and HRMS. 
2.2 Biological results

\subsubsection{Anti-HIV activity of the test compounds}

The new tryptophan derivatives have been evaluated for their inhibitory effects against HIV replication in cell culture. Table 1 summarizes the results of this evaluation. The antiviral data of the best compound (I) of the triazine series is also reported as a reference. Dextran sulfate-5000 (DS-5000), pradimicin A and tenofovir acted as relevant controls. DS-5000 is a negatively charged HIV adsorption inhibitor [17], pradimicin A represents a gp120 carbohydrate-binding entry inhibitor [18] and tenofovir is an HIV RT inhibitor [19]. These compounds showed activities that were in the same range as previously reported [17-19].

None of the compounds $\mathbf{3 a}, \mathbf{3 c}$ and $\mathbf{3 e}$ (nude acids) with free carboxylic acids on the periphery proved inhibitory against HIV $\left(\mathrm{EC}_{50}:>250 \mu \mathrm{M}\right)$. Alternatively compounds 5a-g and 8, with Trps on the periphery, provided significant anti-HIV activity, showing a concentration-dependent inhibition of the virus infection. Some of them showed a markedly improved $(\sim 3-$ to 7-fold) antiviral potency $\left(\mathrm{EC}_{50}\right.$ : lower $\mu \mathrm{M}$ range) than the previously described triazine derivative $\mathrm{I}_{(\mathrm{EC}}$ : $\left.16 \mu \mathrm{M}\right)$. Among these compounds, compounds $\mathbf{5 b}$ and $\mathbf{5 f}$ were the most active $\left(\mathrm{EC}_{50}: 2.6\right.$ and $2.2 \mu \mathrm{M}$ respectively). Compound $\mathbf{5 c}$ showed an $\mathrm{EC}_{50}$ of $4.5 \mu \mathrm{M}$, and proved the least toxic compound in this series $\left(\mathrm{CC}_{50}:>250 \mu \mathrm{M}\right)$, resulting in a selectivity index of $>55$. The compounds tested against HIV-2 (5e-g) also were active at subtoxic concentrations, but the inhibitory potential proved inferior to HIV-1 inhibition.

Compound $\mathbf{5 b}$, containing a rigid central scaffold, and $\mathbf{5 c}$ and $\mathbf{5 d}$, containing more flexible central scaffolds, showed similar anti-HIV-1 activity $\left(\mathrm{EC}_{50}=2.6,4.5\right.$ and $3.2 \mu \mathrm{M}$ respectively). Very comparable data were also obtained for HIV-1 (NL4.3) infection of MT-4 cell cultures $\left(\mathrm{EC}_{50}\right.$ for $\mathbf{5 b}, \mathbf{5 c}$, and $\mathbf{5 d}$ : $1.3,2$ and $2.5 \mu \mathrm{M}$, respectively). From these data it can be concluded that the flexibility of the central core does not play a significant role on activity.

Interestingly, compounds 5e-g, bearing 12, 15 and 18 Trps on the periphery were at least equal (5f) or less (5e, 5g) active than compounds with only 9 Trps (5b-d) showing that the concomitant presence of 9 tryptophan residues on the periphery seems to be sufficient for pronounced anti-HIV activity.

Dendron 8, with 9 Trps on the periphery did not show improved activity compared with dendrimers 5a-d, that also contained 9 Trps on the periphery.

Table 1.

\begin{tabular}{|c|c|c|c|}
\hline Compound & $\begin{array}{c}\mathbf{E C}_{\mathbf{5 0}}{ }^{\mathbf{}}(\boldsymbol{\mu M}) \\
\mathbf{H I V - 1}\end{array}$ & $\begin{array}{c}\mathbf{E C}_{\mathbf{5 0}}{ }^{\mathbf{a}}(\boldsymbol{\mu M}) \\
\mathbf{H I V - 2}\end{array}$ & $\mathbf{C C}_{5 \mathbf{5 0}}{ }^{\mathbf{b}}(\boldsymbol{\mu M})$ \\
\hline $\mathbf{3 a}$ & $>250$ & $>250$ & $>250$ \\
\hline $\mathbf{3 c}$ & $>250$ & $>250$ & $>250$ \\
\hline $\mathbf{3 e}$ & $6.2 \pm 2.5$ & $-^{\mathrm{c}}$ & $>100$ \\
\hline $\mathbf{5 a}$ & $2.6 \pm 2.6$ & $-^{\mathrm{c}}$ & 53 \\
\hline $\mathbf{5 b}$ & $4.5 \pm 4.9$ & $-^{\mathrm{c}}$ & $>250$ \\
\hline $\mathbf{5 c}$ & $3.2 \pm 1.8$ & $-^{\mathrm{c}}$ & 59 \\
\hline $\mathbf{5 d}$ & $11.3 \pm 2.8$ & $\geq 30$ & $>30$ \\
\hline $\mathbf{5 e}$ & $2.2 \pm 2.1$ & 10 & $>100$ \\
\hline $\mathbf{5 f}$ & & & \\
\hline
\end{tabular}




\begin{tabular}{|c|c|c|c|}
\hline $\mathbf{5 g}$ & $8.0 \pm 2.1$ & 30 & $>100$ \\
\hline $\mathbf{8}$ & $9.9 \pm 1.6$ & $44 \pm 2.8$ & $>100$ \\
\hline $\mathbf{I}$ & $16 \pm 0.71$ & $22 \pm 2.8$ & $>250$ \\
\hline DS-5000 & $0.07 \pm 0.02$ & $0.03 \pm 0.01$ & $>20$ \\
\hline Pradimicin A & $3.3 \pm 1.2$ & $5.9 \pm 3.7$ & $>100$ \\
\hline Tenofovir & $3.9 \pm 0.9$ & $3.7 \pm 1.2$ & $>100$ \\
\hline
\end{tabular}

\footnotetext{
Data are the mean \pm S.D. of at least 2 to 3 independient experiments

a $50 \%$ Effective concentration, or the concentration required to inhibit HIV-induced cytopathicity by $50 \%$

${ }^{\mathrm{b}} 50 \%$ Cytostatic concentration, or the concentration required to inhibit CEM cell proliferation by $50 \%$

${ }^{\mathrm{c}}$ Not tested
}

\subsubsection{Time-of-addition experiments}

In order to reveal which particular stage of the HIV replicative cycle was inhibited by the compounds, time-of-addition (TOA) experiments [20,21] were performed with the selected active compounds $\mathbf{5 b}$ and $\mathbf{5 f}$. In this experiment, the virusassociated p24 antigen (p24 is the major structural protein of the virion), quantified by a commercially available ELISA assay (Enzyme-linked immunosorbent assay), was used to examine HIV replication. At different time-points after virus infection, the test compounds were added to the virus-infected cell cultures. If a compound inhibits virus infection at an early stage in the virus replicative cycle, addition of such compound cannot be too much delayed in the virus-infected cultures without losing its antiviral activity. Instead, if a compound acts at a late stage in the virus replicative cycle, addition of such compound can be much longer delayed in the virus-infected cell cultures before losing its antiviral efficacy. Different well-characterized anti-HIV drugs were therefore used as reference drugs. As inhibitors of the entry/fusion process the carbohydrate-binding pradimicin $S$ (PRM-S), the CXCR4 antagonist bicyclam AMD3100 and the adsorption inhibitor DS8,000 were used. AZT was used as reverse transcriptase inhibitor. The protease inhibitor ritonavir was also included in the study to reflect an agent that acts late in the viral replication cycle.

As it was shown in Figure 2 the curves for compounds $\mathbf{5 b}$ and $\mathbf{5 f}$ nicely overlap with those of the established entry inhibitors. Thus, this experiment clearly shows that $\mathbf{5 b}$ and $\mathbf{5 f}$ inhibit early step(s) of the replicative cycle of HIV, and more specifically they inhibit the entry of the virus into its target cells. This target may be not so unlikely since the investigated structures have a rather high molecular weight, and thus, it might be most likely, although not proven, that they are not efficiently taken-up by the exposed infected cells. The rather step dose-response inhibition curves of $\mathbf{5 b}$ and $\mathbf{5} \mathbf{f}$ obviously resulted in the full inhibition of HIV replication (i.e. entry) when continuously present at the start of the virus infection (zero time point) at $10 \mu \mathrm{M}$.

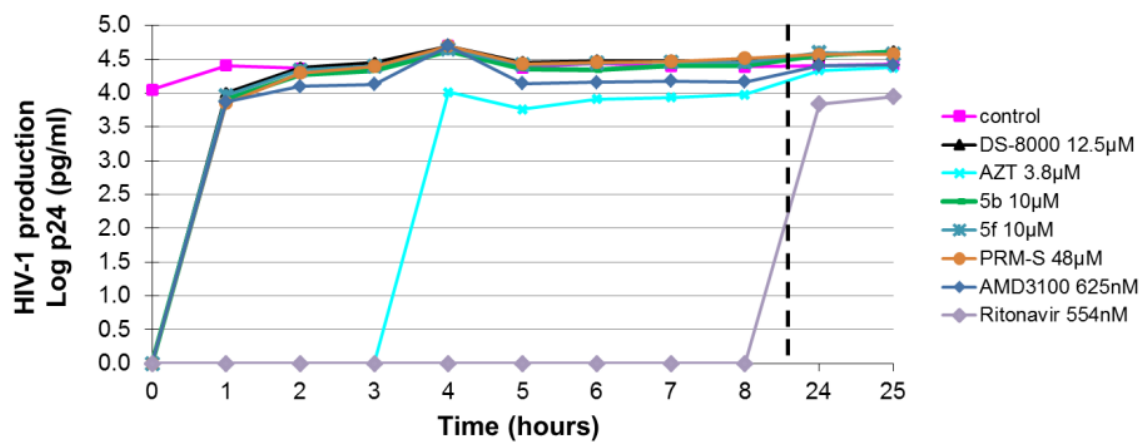

Fig. 2. 


\subsubsection{SPR experiments}

The compounds found inhibitory against HIV-1 in cell culture presumably inhibit HIV entry into its target cells as based on the target profiling found in time-of-addition experiments. It would, therefore, be of particular interest to investigate potential binding of the compounds to the virus-encoded gp120/gp41 envelope glycoproteins. Using surface plasmon resonance (SPR) technology, recombinant HIV-1 III $_{\mathrm{B}}$ gp120 and HIV-1 HxB2 gp41 (produced in Chinese hamster ovary cells) were bound to a sensor chip as monomers and the interaction of the compounds with the viral envelope glycoproteins were determined at one fixed concentration $(50 \mu \mathrm{M})$. The two dendrimers that contained the highest number of tryptophans on the periphery, $\mathbf{5 f}$ (15 Trp) and 5g (18 Trp), showed the highest binding signal to both gp120 and gp41 (Fig. 3). The highest binding efficiency was then followed by compounds $\mathbf{5 a - d}$. Compound $\mathbf{5 c}$, containing the cyclohexyl core, was slightly better than 5a,b,d. Compound 5e and $\mathbf{8}$ showed clearly an inferior binding amplitude to gp120 and gp41 than the other compounds (data not shown).
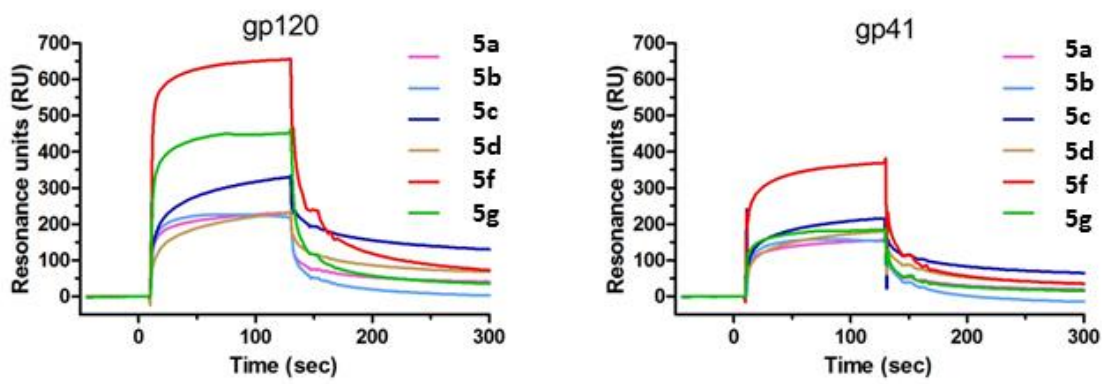

Fig. 3.

Detailed SPR-directed affinities were then measured for $\mathbf{5 f}$ that proved to be the most efficient binding derivative to gp120/gp41. For this purpose compound concentrations ranging between 0 and $40 \mu \mathrm{M}$ were used. The apparent $K_{D}$ value for $\mathbf{5 f}$ binding to gp120 (Figure 1 Suplementary Material and Table 2) was in the low micromolar range $\left(\mathrm{K}_{\mathrm{D}}: 6.7 \mu \mathrm{M}\right)$, being 2 times more pronounced than those found for the triazine prototype I $\left(\mathrm{K}_{\mathrm{D}}: 14 \mu \mathrm{M}\right)$, showing that the affinity of $\mathbf{5 f}$ to gp120 is 2-fold more pronounced than that observed for $\mathbf{I}$. The apparent $K_{D}$ value for $\mathbf{5 f}$ binding to gp41 was $18 \mu \mathrm{M}$, that means that the interaction of $\mathbf{5 f}$ with gp41 was 3-fold less pronounced than with gp120.

Table 2.

\begin{tabular}{|c|c|}
\hline Complex & $\mathrm{K}_{\mathrm{D}}(\mu \mathrm{M})$ \\
\hline 5f-gp120 & 6.7 \\
\hline 5f-gp41 & 18 \\
\hline I-gp120 & 14 \\
\hline
\end{tabular}

The polyanionic nature of $\mathbf{5 f}$ may rise the question whether the observed affinity for HIV-1 gp120 is due to the binding to the positively charged V3 loop of gp120 or whether the compound binds to other areas on gp120 such as the glycans present on this glycoprotein [22]. To solve this question, the association and dissociation of $\mathbf{5 f}$ to the gp120-bound sensorchip was also 
studied in the presence of the mannose trimer $\operatorname{mann}(\alpha-1,3-1,6)_{3}$, that represents a mannose oligomer composition that is also present in gp120 glycans. As shown in Figure 4 this mannose trimer was not at all able to affect the interaction of compound $\mathbf{5 f}$ with gp120, neither with gp41. This finding suggests that compound $\mathbf{5 f}$ may interact with gp120 and gp41 in a manner that is different from mannose $\alpha 1,3 / \alpha 1,6$ oligomer binding.
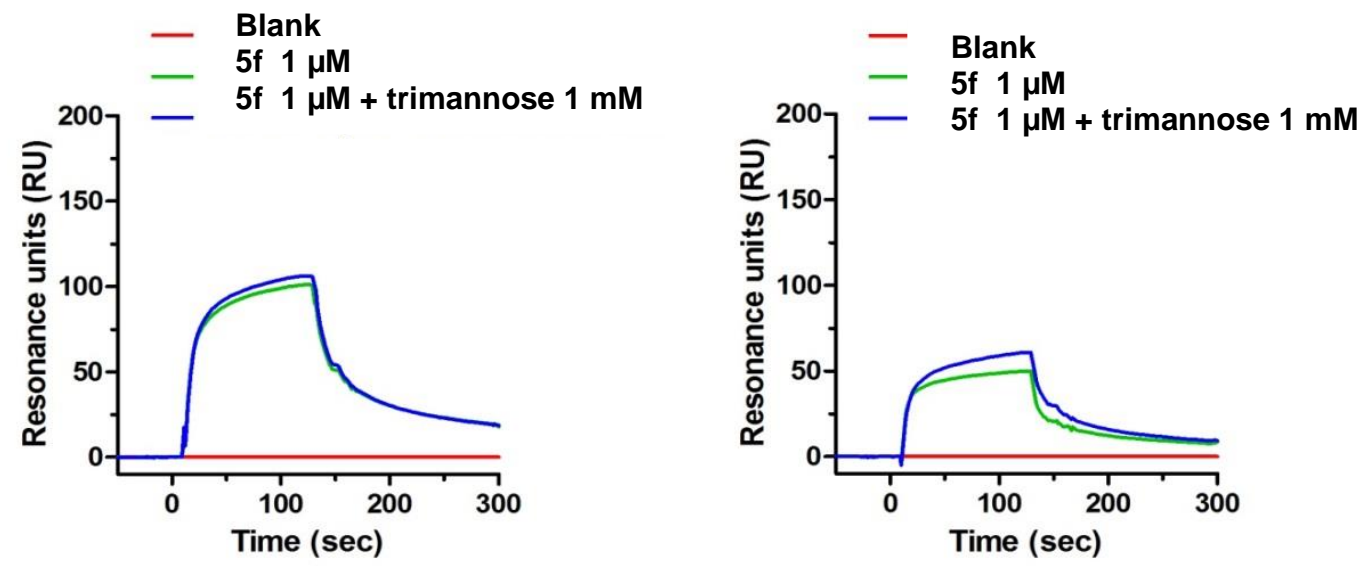

Fig. 4.

\section{Conclusions}

Dendrimers with more than six tryptophan residues (i.e. 9, 12, 15 and 18) on the periphery have been readily prepared by combining a core structure of $3,4,5$ or 6 carboxylic acids with an amino triester as branching unit. These compounds have been evaluated as anti-HIV agents in cell culture. Several of them showed a markedly improved ( 3- to 7-fold) antiviral potency $\left(\mathrm{EC}_{50}\right.$ : lower $\mu \mathrm{M}$ range) than the previously described triazine derivative $\mathbf{I}\left(\mathrm{EC}_{50}: 16 \mu \mathrm{M}\right)$, with six tryptophan residues on the periphery. Selectivity indices were often $>10$ - to $>55$-fold.

The results obtained so far indicate that the presence of Trp (at least at a total of 9 residues on the periphery) is crucial for the antiviral activity since the compounds without this moiety (nude acids) were inactive against HIV. The triazine moiety present in $\mathbf{I}$ is not crucial for activity. This moiety can be substituted by other simplified spacer arms. The rigidity of the central scaffold does not appear to be important for antiviral activity.

Time-of-addition (TOA) experiments carried out with two representative members of this compound family, i.e. $\mathbf{5 b}$ and $\mathbf{5 f}$, clearly show that these compounds inhibit early steps of the replicative cycle of HIV, presumably virus entry into its target cells. Surface plasmon resonance (SPR) studies revealed that all compounds showed binding to HIV-1 gp120 and gp41.

Compound $\mathbf{5 f}$, containing 15 tryptophans on the periphery, showed the most significant anti-HIV-1 activity $\left(\mathrm{EC}_{50}: 2.2 \mu \mathrm{M}\right)$ and pronounced interaction with gp120/gp41.

\section{Materials and methods}

\subsection{Synthesis}

\subsubsection{General Procedure for the synthesis of dendrimers $\mathbf{3 a - g}$}

To a solution containing the corresponding central scaffold a-g in DMF (20 mL), aminotriester 1 [12] (1.5 eq for each carboxylic acid group), HATU (1.5 eq for each carboxylic acid group) and DIPEA (4.5 eq for each carboxylic acid group) were added. The reaction mixture was stirred at room temperature during 2 days and then evaporated to dryness. The residue was 
dissolved in dichloromethane $(50 \mathrm{~mL})$ and washed successively with aqueous solutions of citric acid $(10 \%)(3 \times 20 \mathrm{~mL})$, saturated $\mathrm{NaHCO}_{3}(3 \times 20 \mathrm{~mL})$, and brine $(3 \times 20 \mathrm{~mL})$. The organic phase was dried over anhydrous $\mathrm{Na}_{2} \mathrm{SO}_{4}$, filtered, and evaporated to dryness. The residue, without further purification, was subsequently dissolved in formic acid and the solution was stirred at $40^{\circ} \mathrm{C}$ for $48 \mathrm{~h}$. After cooling, volatiles were evaporated to dryness and the residue was dissolved in methanol and treated with ethyl acetate to give the corresponding dendrimer 3a-g with 9, 12, 15 or 18 carboxylic acids on the periphery as a pale yellow solid.

\subsubsection{Dendrimer nonaacid (3a)}

According to the general procedure a solution of 1,3,5-triethyl-2,4,6-tris(carboxymethyl)benzene a [13] (400 mg, 1.2 mmol), aminotriester 1 [12] (2.24 g, $5.4 \mathrm{mmol})$, HATU (2.03 g, $5.4 \mathrm{mmol})$ and DIPEA (2.9 mL, $16.2 \mathrm{mmol})$ in DMF (20 mL) gave $1.28 \mathrm{~g}(99 \%)$ of $\mathbf{3 a}$ as a pale yellow solid; m.p. 170-172 ${ }^{\circ} \mathrm{C} .{ }^{1} \mathrm{H}$ NMR $\left(300 \mathrm{MHz}, \mathrm{DMSO}-\mathrm{d}_{6}\right) \delta: 0.98\left(\mathrm{~m}, 9 \mathrm{H}, \mathrm{CH}_{3} \mathrm{CH}_{2}\right)$, $1.60\left(\mathrm{~m}, 9 \mathrm{H}, \mathrm{CH}_{2}\right), 1.75\left(\mathrm{~m}, 9 \mathrm{H}, \mathrm{CH}_{2}\right), 2.19\left(\mathrm{~m}, 9 \mathrm{H}, \mathrm{CH}_{2}\right), 2.25\left(\mathrm{~m}, 9 \mathrm{H}, \mathrm{CH}_{2}\right), 2.52\left(\mathrm{~m}, 6 \mathrm{H}, \mathrm{CH}_{2} \mathrm{CH}_{3}\right), 3,60\left(\mathrm{~m}, 6 \mathrm{H}, \mathrm{CH}_{2} \mathrm{CO}\right)$, 7,65 (bs, 3H, NH). HRMS (ESI') $m / z$ : Calcd. for $\mathrm{C}_{48} \mathrm{H}_{69} \mathrm{~N}_{3} \mathrm{O}_{21}$ 1023.4424. Found 1023.4460.

\subsubsection{Dendrimer nonaacid (3c)}

According to the general procedure a solution of cis,cis-1,3,5-cyclohexantricarboxylic acid c (200 $\mathrm{mg}, 0.93 \mathrm{mmol})$, aminotriester 1 [12] (1.69 g, $4.19 \mathrm{mmol})$, HATU (1.58 g, $4.19 \mathrm{mmol})$ and DIPEA (2.26 mL, $12.6 \mathrm{mmol})$ in DMF (20 mL) afforded $784 \mathrm{mg}(94 \%)$ of $3 \mathrm{c}$ as a pale yellow solid; m.p. $247-249{ }^{\circ} \mathrm{C} .{ }^{1} \mathrm{H}$ NMR $\left(400 \mathrm{MHz}, \mathrm{DMSO}-\mathrm{d}_{6}\right) \delta: 1.78\left(\mathrm{~m}, 21 \mathrm{H}, \mathrm{CH}_{2}\right.$, $\mathrm{CH}), 2.05$ (m, 24H, $\left.\mathrm{CH}_{2}, \mathrm{CH}\right), 7.09$ (s, 3H, NH), 11.96 (bs, 9H, COOH). ${ }^{13} \mathrm{C}$ NMR $\left(125 \mathrm{MHz}, \mathrm{CD}_{3} \mathrm{OD}\right) \delta: 29.44\left(\mathrm{CH}_{2}\right), 30.40$ $\left(\mathrm{CH}_{2}\right), 31.98\left(\mathrm{CH}_{2}\right), 32.74\left(\mathrm{CH}_{2}\right), 57.44(\mathrm{C}), 175.36(\mathrm{C}=\mathrm{O}), 175.77(\mathrm{C}=\mathrm{O})$. HRMS (ESI $)$ m/z: Calcd. for $\mathrm{C}_{39} \mathrm{H}_{57} \mathrm{~N}_{3} \mathrm{O}_{21}$ 903.3485. Found 903.3489.

\subsubsection{Dendrimer dodecaacid (3e)}

According to the general procedure a solution of ethylenediaminetetraacetic acid (EDTA) compound e (100 mg, $0.34 \mathrm{mmol})$, aminotriester 1 [12] (2.04 g, $2.04 \mathrm{mmol})$, HATU (954 mg, $2.04 \mathrm{mmol})$ and DIPEA (2.13 mL, $6.12 \mathrm{mmol})$ in DMF (20 mL) afforded $340 \mathrm{mg}(82 \%)$ of 3e as a pale yellow solid; m.p. $173-175{ }^{\circ} \mathrm{C} .{ }^{1} \mathrm{H}$ NMR $\left(500 \mathrm{MHz}, \mathrm{CD}_{3} \mathrm{OD}\right) \delta: 2.64\left(\mathrm{~m}, 24 \mathrm{H}, \mathrm{CH}_{2}\right)$, $2.91\left(\mathrm{~m}, 24 \mathrm{H}, \mathrm{CH}_{2}\right), 3.42\left(\mathrm{~s}, 4 \mathrm{H}, \mathrm{CH}_{2}\right), 3.88\left(\mathrm{~m}, 8 \mathrm{H}, \mathrm{CH}_{2} \mathrm{NH}\right), 8.47(\mathrm{~m}, 4 \mathrm{H}, \mathrm{NH}) .{ }^{13} \mathrm{C} \mathrm{NMR}\left(125 \mathrm{MHz}, \mathrm{CD}_{3} \mathrm{OD}\right) \delta: 29.62\left(\mathrm{CH}_{2}\right)$, $30.51\left(\mathrm{CH}_{2}\right), 53.84(\mathrm{C}), 57.85\left(\mathrm{CH}_{2}\right), 59.77\left(\mathrm{CH}_{2}\right), 171.17(\mathrm{C}=\mathrm{O}), 175.88(\mathrm{C}=\mathrm{O})$. HRMS (ESI $) m / z:$ Calc. for $\mathrm{C}_{50} \mathrm{H}_{76} \mathrm{~N}_{6} \mathrm{O}_{28}$ 1209.1588. Found 1209.1584.

\subsubsection{Dendrimer pentadecaacid (3f)}

According to the general procedure a solution of penta(carboxymethyl)diethylenetriamine (DTPA) f (400 mg, $1.02 \mathrm{mmol}$ ), aminotriester 1 [12] (3.20 g, $7.6 \mathrm{mmol})$, HATU (2.94 g, $7.6 \mathrm{mmol})$ and DIPEA (4.1 mL, $22.95 \mathrm{mmol})$ in DMF (20 mL) afforded 1,10 g (80\%) of $\mathbf{3 f}$ as a pale yellow solid; m.p. 184-186 ${ }^{\circ} \mathrm{C} .{ }^{1} \mathrm{H}$ NMR (400 MHz, DMSO-d 6 ) $\delta: 1.63(\mathrm{t}, J=7.1 \mathrm{~Hz}$, $\left.30 \mathrm{H}, \mathrm{CH}_{2}\right), 2.14\left(\mathrm{~m}, 8 \mathrm{H}, \mathrm{CH}_{2}\right), 2.19\left(\mathrm{t}, J=7.5 \mathrm{~Hz}, 30 \mathrm{H}, \mathrm{CH}_{2}\right), 3.03\left(\mathrm{~s}, 10 \mathrm{H}, \mathrm{NCH}_{2}\right)$. HRMS (ESI) $m / z$ : Cald. for $\mathrm{C}_{64} \mathrm{H}_{98} \mathrm{~N}_{8} \mathrm{O}_{35}$ 1538.6135. Found 1538.6216. 
4.1.6. Dendrimer octadecaacid $(\mathbf{3 g})$

According to the general procedure a solution of hexa(carboxymethyl)triethylenetetramine $\mathbf{g}(500 \mathrm{mg}, 1.01 \mathrm{mmol})$, aminotriester 1 [12] (3.73 g, $9.09 \mathrm{mmol})$, HATU (3.46 g, $9.09 \mathrm{mmol})$ and DIPEA (4.76 mL, $27.27 \mathrm{mmol})$ in DMF (20 mL) afforded $1.55 \mathrm{~g}(88 \%)$ of $\mathbf{3 g}$ as a pale yellow solid; m.p.: 183-185 ${ }^{\circ} \mathrm{C} .{ }^{1} \mathrm{H}$ NMR $\left(300 \mathrm{MHz}, \mathrm{DMSO}-\mathrm{d}_{6}\right) \delta: 1.83\left(\mathrm{~m}, 36 \mathrm{H}, \mathrm{CH}_{2}\right)$, $2.11\left(\mathrm{~m}, 36 \mathrm{H}, \mathrm{CH}_{2}\right), 2.26\left(\mathrm{~m}, 12 \mathrm{H}, \mathrm{CH}_{2}\right), 3.08$ (bs, 12H, $\mathrm{NCH}_{2}$ ). HRMS (ESI') m/z: Cald. for $\mathrm{C}_{78} \mathrm{H}_{120} \mathrm{~N}_{10} \mathrm{O}_{42}$ 1868.7562. Found 1868.7542 .

\subsubsection{General Procedure for the synthesis of OBn or OMe protected Trp dendrimers ( $\mathbf{4} \mathbf{a - g}$ )}

To a mixture of the corresponding poly acid 3a-g and H-(L)-Trp-OMe.HCl or H-(L)-Trp-OBzl.HCl (1.5 eq for each carboxylic acid group) in DMF (20 mL), HATU (1.5 eq for each carboxylic acid group) and DIPEA (4.5 eq for each carboxylic acid group) were added. The reaction was stirred at room temperature during 3 days (for compounds with 9 or 12 Trp moieties) or 4 days (for compounds with 15 or 18 Trp moieties) and then evaporated to dryness to afford a residue that was dissolved in dichloromethane $(30 \mathrm{~mL})$ and washed successively with aqueous solutions of citric acid $(10 \%)(3 \times 20 \mathrm{~mL})$, saturated $\mathrm{NaHCO}_{3}$ $(3 \times 20 \mathrm{~mL})$, and brine $(3 \times 20 \mathrm{~mL})$. The organic layer was dried over anhydrous $\mathrm{Na}_{2} \mathrm{SO}_{4}$, filtered and evaporated. The residue was purified on a Biotage HPFC (High Performance Flash Chromatography) purification system on reverse phase using water/acetonitrile (100:0 to 0:100) as eluent.

\subsubsection{Dendrimer $(4 a)$}

According to the general procedure a mixture containing 3a (250 mg, $0.24 \mathrm{mmol}), \mathrm{H}-(\mathrm{L})-\mathrm{Trp}-\mathrm{OMe} . \mathrm{HCl}$ (825 mg, 3.24 mmol), HATU (1.23 g, $3.24 \mathrm{mmol})$ and DIPEA (1.74 mL, $9.72 \mathrm{mmol})$ in DMF (20 mL) gave $245 \mathrm{mg}(36 \%)$ of $4 \mathbf{a}$ as an amorphous yellow solid. ${ }^{1} \mathrm{H}-\mathrm{RMN}\left(300 \mathrm{MHz}, \mathrm{CDCl}_{3}\right) \delta: 1.25\left(\mathrm{~m}, 9 \mathrm{H}, \mathrm{CH}_{3} \mathrm{CH}_{2}\right), 1.80\left(\mathrm{~m}, 18 \mathrm{H}, \mathrm{CH}_{2}\right), 2.31\left(\mathrm{~m}, 24 \mathrm{H}, \mathrm{CH}_{2}\right.$, $\left.\mathrm{CH}_{3} \mathrm{CH}_{2}\right), 3.09$ (m, 9H, $\left.\beta-\mathrm{CH}_{2} \mathrm{Trp}\right), 3.26\left(\mathrm{~m}, 9 \mathrm{H}, \beta-\mathrm{CH}_{2} \mathrm{Trp}\right), 3.62\left(\mathrm{~s}, 27 \mathrm{H}, \mathrm{OCH}_{3}\right), 3.79\left(\mathrm{~m}, 6 \mathrm{H}, \mathrm{CH}_{2} \mathrm{CO}\right), 4.74(\mathrm{~m}, 9 \mathrm{H}, \alpha-$ CHTrp), 6.99-7.47 (m, 45H, Ar), 7.98 (s, 3H, NH), 9.04 (m, 9H, NH). HRMS (ESI ${ }^{+}$) m/z: Cald. for $\mathrm{C}_{156} \mathrm{H}_{177} \mathrm{~N}_{21} \mathrm{O}_{30} 2824.2970$. Found 2824.3040.

\subsubsection{Dendrimer $(\mathbf{4 b})$}

According to the general procedure a mixture containing $3 \mathbf{b}(250 \mathrm{mg}, 0.24 \mathrm{mmol}), \mathrm{H}-(\mathrm{L})-\mathrm{Trp}-\mathrm{OBzl} . \mathrm{HCl}(1.07 \mathrm{~g}, 3.24$ mmol), HATU (1.23 g, $3.24 \mathrm{mmol})$ and DIPEA (1.74 mL, $9.72 \mathrm{mmol})$ in DMF (20 mL) gave $880 \mathrm{mg}(94 \%)$ of $4 \mathbf{b}$ as an amorphous yellow solid. ${ }^{1} \mathrm{H}$ NMR $\left(300 \mathrm{MHz}, \mathrm{CDCl}_{3}\right) \delta: 2.40\left(\mathrm{~m}, 18 \mathrm{H}, \mathrm{CH}_{2}\right), 2.67\left(\mathrm{~m}, 18 \mathrm{H}, \mathrm{CH}_{2}\right), 3.29(\mathrm{dd}, J=14.9 \mathrm{~Hz}, J=$ $\left.7.8 \mathrm{~Hz}, 9 \mathrm{H}, \beta-\mathrm{CH}_{2} \mathrm{Trp}\right), 3.44$ (m, 9H, $\left.\beta-\mathrm{CH}_{2} \mathrm{Trp}\right), 4.41$ (td, $J=7.7 \mathrm{~Hz}, J=4.4 \mathrm{~Hz}, 9 \mathrm{H}, \alpha$-CHTrp), 5.13 (dd, $J=14.1 \mathrm{~Hz}, J=2.3$ $\mathrm{Hz}, 18 \mathrm{H}, \mathrm{CH}_{2} \mathrm{Ar}$ ), 7.03-7.47 (m, 90H, Ar), 8.73 (m, 6H, Ar, NH). HRMS (ESI ${ }^{+}$) m/z: Cald. for $\mathrm{C}_{201} \mathrm{H}_{195} \mathrm{~N}_{21} \mathrm{O}_{30} 3382.4379$. Found 3382.4370.

\subsubsection{Dendrimer $(4 c)$}

According to the general procedure a mixture containing 3c (450 mg, $0.5 \mathrm{mmol}), \mathrm{H}-(\mathrm{L})$-Trp-OBzl.HCl (2.01 g, $6.21 \mathrm{mmol})$, HATU (2.36 g, $6.21 \mathrm{mmol})$ and DIPEA $(3.57 \mathrm{~mL}, 20.25 \mathrm{mmol})$ in DMF (20 mL), afforded $1.46 \mathrm{~g}(86 \%)$ of $4 \mathbf{c}$ as an amorphous yellow solid. ${ }^{1} \mathrm{H}$ NMR (300 MHz, $\left.\mathrm{CDCl}_{3}\right) \delta: 1.93-2.44$ (m, 45H, $\left.\mathrm{CH}_{2}, \mathrm{CH}\right), 3.19$ (m, $\left.18 \mathrm{H}, \beta-\mathrm{CH}_{2} \operatorname{Trp}\right), 4.80$ (s, 9H, $\alpha$-CHTrp), 5.03 (m, 18H, $\mathrm{CH}_{2} \mathrm{Ar}$ ), 6.85-7.27 (m, 90H, Ar), 9.04 (m, 9H, NH). HRMS (ESI ${ }^{+}$) m/z: Cald. for $\mathrm{C}_{201} \mathrm{H}_{201} \mathrm{~N}_{21} \mathrm{O}_{30} 3388.4848$. Found 3388.4859. 


\subsubsection{Dendrimer (4d)}

According to the general procedure a mixture containing 3d (400 mg, $0.46 \mathrm{mmol}), \mathrm{H}-(\mathrm{L})-\mathrm{Trp}-\mathrm{OMe} . \mathrm{HCl}(1.58 \mathrm{~g}, 6.21$ mmol), HATU (2.36 g, $6.21 \mathrm{mmol})$ and DIPEA (3.25 mL, $18.63 \mathrm{mmol})$ in DMF (20 mL) afforded $1.00 \mathrm{~g}(82 \%)$ of $4 \mathbf{d}$ as an amorphous yellow solid. ${ }^{1} \mathrm{H}$ NMR $\left(300 \mathrm{MHz}_{\mathrm{CDCl}}\right) \delta: 1.50\left(\mathrm{~m}, 18 \mathrm{H}, \mathrm{CH}_{2}\right), 1.78\left(\mathrm{~m}, 18 \mathrm{H}, \mathrm{CH}_{2}\right), 3.06\left(\mathrm{~m}, 9 \mathrm{H}, \beta-\mathrm{CH}_{2} \mathrm{Trp}\right)$, 3.25 (m, 15H, $\left.\beta-\mathrm{CH}_{2} \operatorname{Trp}, \mathrm{CH}_{2} \mathrm{NH}\right), 3.62$ (s, 27H, OCH $), 4.80$ (m, 9H, $\left.\alpha-\mathrm{CHTrp}\right), 6.82-7,75$ (m, 90H, Ar), 9.82 (bs, $\left.12 \mathrm{H}, \mathrm{NH}\right)$.

${ }^{13} \mathrm{C}$ NMR (75 MHz, $\left.\mathrm{CDCl}_{3}\right)$ \&: $27.53\left(\mathrm{CH}_{3}\right), 30.22\left(\mathrm{CH}_{2}\right), 52.71\left(\mathrm{CH}_{2}\right), 53.28\left(\mathrm{CH}_{2}\right), 53.82(\mathrm{C}), 58.07(\mathrm{CH}), 109.96(\mathrm{C}), 111.84$ $(\mathrm{CH}), 118.49(\mathrm{CH}), 119.55(\mathrm{CH}), 122.15(\mathrm{CH}), 123.89(\mathrm{CH}), 127.43(\mathrm{C}), 136.56(\mathrm{C}), 170.82(\mathrm{C}=\mathrm{O}), 173.21(\mathrm{C}=\mathrm{O}), 174.37$ $(\mathrm{C}=\mathrm{O})$. HRMS $\left(\mathrm{ESI}^{+}\right) \mathrm{m} / \mathrm{z}$ : Cald. for $\mathrm{C}_{144} \mathrm{H}_{162} \mathrm{~N}_{22} \mathrm{O}_{30} 2679.1827$. Found 2679.1739.

\subsubsection{Dendrimer (4e)}

According to the general procedure a mixture containing 3e $(150 \mathrm{mg}, 0.12 \mathrm{mmol}), \mathrm{H}-(\mathrm{L})-\mathrm{Trp}-\mathrm{OBzl} . \mathrm{HCl}(714 \mathrm{mg}, 1.92$ mmol), HATU (821 mg, $1.92 \mathrm{mmol})$ and DIPEA $(1.13 \mathrm{~mL}, 6.48 \mathrm{mmol})$ in DMF (20 mL), afforded $345 \mathrm{mg}(61 \%)$ of $4 \mathbf{e}$ as an amorphous yellow solid. ${ }^{1} \mathrm{H}$ NMR $\left(300 \mathrm{MHz}, \mathrm{CDCl}_{3}\right) \delta: 2.46\left(\mathrm{~m}, 24 \mathrm{H}, \mathrm{CH}_{2}\right), 2.76\left(\mathrm{~m}, 28 \mathrm{H}, \mathrm{CH}_{2}\right), 3.31-3.38(\mathrm{~m}, 20 \mathrm{H}, \beta-$ $\left.\mathrm{CH}_{2} \mathrm{Trp}, \mathrm{CH}_{2} \mathrm{NH}\right), 3.50\left(\mathrm{dd}, 12 \mathrm{H}, J=14.9 \mathrm{~Hz}, J=3.5 \mathrm{~Hz}, \beta-\mathrm{CH}_{2} \mathrm{Trp}\right), 4.44$ (m, 12H, $\left.\alpha-\mathrm{CHTrp}\right), 5.19$ (d, $\left.24 \mathrm{H}, \mathrm{CH}_{2} \mathrm{Ar}\right), 5.76$ (d, $J=4.25 \mathrm{~Hz}, 4 \mathrm{H}), 7.07-7.50\left(\mathrm{~m}, 120 \mathrm{H}, \mathrm{H}-2^{\mathrm{i}} \mathrm{Trp}, \mathrm{Ar}\right), 8.02(\mathrm{~s}, 12 \mathrm{H}, \mathrm{NH}), 8.75(\mathrm{~s}, 4 \mathrm{H}, \mathrm{NH})$. HRMS $\left(\mathrm{ESI}^{+}\right) \mathrm{m} / z$ : Cald. for $\mathrm{C}_{266} \mathrm{H}_{268} \mathrm{~N}_{30} \mathrm{O}_{40} 4521.9859$. Found 4521.9927.

\subsubsection{Dendrimer (4f)}

According to the general procedure a mixture containing $3 f(500 \mathrm{mg}, 0.32 \mathrm{mmol}), \mathrm{H}-(\mathrm{L})-\mathrm{Trp}-\mathrm{OMe} . \mathrm{HCl}(1.83 \mathrm{~g}, 7.2 \mathrm{mmol})$, HATU (2.79 g, $7.2 \mathrm{mmol})$ and DIPEA (3.96 mL, $21.6 \mathrm{mmol})$ in DMF (20 mL) afforded $771 \mathrm{mg}(60 \%)$ of $4 \mathbf{f}$ as an amorphous yellow solid. ${ }^{1} \mathrm{H}$ NMR (400 MHz, $\left.\mathrm{CDCl}_{3}\right) \delta: 1.43\left(\mathrm{~m}, 30 \mathrm{H}, \mathrm{CH}_{2}\right), 1.94\left(\mathrm{~m}, 30 \mathrm{H}, \mathrm{CH}_{2}\right), 2.18\left(\mathrm{~m}, 8 \mathrm{H}, \mathrm{CH}_{2}\right), 3.28(\mathrm{~m}, 30 \mathrm{H}, \beta-$ $\left.\mathrm{CH}_{2} \mathrm{Trp}\right), 3.49$ (s, 10H, $\mathrm{NCH}_{2}$ ), 3.67 (m, 45H, $\mathrm{OCH}_{3}$ ), 4.88 (m, 15H, $\alpha$-CHTrp), 6.95-7.49 (m, 75H, H-2 Trp, Ar), 8.77 (m, $15 \mathrm{H}$, NH). HRMS (ESI $\left.{ }^{+}\right) m / z$ : Cald. for $\mathrm{C}_{244} \mathrm{H}_{278} \mathrm{~N}_{38} \mathrm{O}_{50} 4540.0379$. Found 4540.0424.

\subsubsection{Dendrimer $(\mathbf{4 g})$}

According to the general procedure a mixture containing $3 \mathrm{~g}(550 \mathrm{mg}, 0.29 \mathrm{mmol}), \mathrm{H}-(\mathrm{L})-\mathrm{Trp}-\mathrm{OMe} . \mathrm{HCl}(1.99 \mathrm{~g}, 7.83$ mmol), HATU (2.9 g, $7.83 \mathrm{mmol})$ and DIPEA (4.1 mL, $23.49 \mathrm{mmol})$ in DMF (20 mL) afforded $561 \mathrm{mg}(35 \%)$ of $\mathbf{4 g}$ as an amorphous yellow solid. ${ }^{1} \mathrm{H}$ NMR $\left(400 \mathrm{MHz}, \mathrm{CDCl}_{3}\right) \delta: 1.52\left(\mathrm{~m}, 36 \mathrm{H}, \mathrm{CH}_{2}\right), 1.94\left(\mathrm{~m}, 36 \mathrm{H}, \mathrm{CH}_{2}\right), 2.20\left(\mathrm{~m}, 12 \mathrm{H}, \mathrm{CH}_{2}\right), 3.30(\mathrm{~m}$, $\left.36 \mathrm{H}, \beta-\mathrm{CH}_{2} \mathrm{Trp}\right), 3.45\left(\mathrm{~s}, 12 \mathrm{H}, \mathrm{NCH}_{2}\right), 3.62\left(\mathrm{~m}, 54 \mathrm{H}, \mathrm{OCH}_{3}\right), 4.86(\mathrm{~m}, 18 \mathrm{H}, \alpha-\mathrm{CHTrp}), 6.95-7.45\left(\mathrm{~m}, 90 \mathrm{H}, \mathrm{H}-2^{\mathrm{i}} \mathrm{Trp}, \mathrm{Ar}\right), 8.50$ (m, 18H, NH). HRMS (ESI $\left.{ }^{+}\right) m / z$ : Cald. for $\mathrm{C}_{294} \mathrm{H}_{336} \mathrm{~N}_{46} \mathrm{O}_{60} 5470.4655$. Found 5470.4648.

\subsubsection{General Procedure for the deprotection of the methyl esters $4 \boldsymbol{a}, \boldsymbol{d}, \boldsymbol{f}, \boldsymbol{g}$}

To a solution containing the corresponding methyl ester derivative $(1.0 \mathrm{mmol})$ in THF $(10 \mathrm{ml})$, a solution of $\mathrm{LiOH} \cdot \mathrm{H}_{2} \mathrm{O}(2$ equiv. for each methyl ester group) in water $(10 \mathrm{ml})$ was added, and the mixture was stirred at room temperature during 3 days (for compounds with 9 or 12 tryptophan residues) or 5 days (for compounds with 15 or 18 tryptophan residues). Then, formic acid was added to reach $\mathrm{pH}=2$, and volatiles were evaporated to dryness. The residue was purified on a Biotage HPFC system (High Performance Flash Chromatography) on reverse phase using water/acetonitrile (100:0 to 0:100) as eluent. 


\subsubsection{Dendrimer (5a)}

Following the general procedure for the deprotection of methyl esters, compound 4a (245 mg, $0.09 \mathrm{mmol})$ gave $100 \mathrm{mg}$ (43\%) of $\mathbf{5 a}$ as an amorphous white solid. ${ }^{1} \mathrm{H}$ NMR (500 MHz, DMSO-d 6 ) $\delta: 0.91\left(\mathrm{~m}, 9 \mathrm{H}, \mathrm{CH}_{3} \mathrm{CH}_{2}\right), 1.67\left(\mathrm{~m}, 24 \mathrm{H}, \mathrm{CH}_{2}\right), 1.97$ (m, 18H, $\mathrm{CH}_{2}$ ), 2.47 (m, 6H, $\mathrm{CH}_{3} \mathrm{CH}_{2}$ ), 3.12 (m, 9H, $\left.\beta-\mathrm{CH}_{2} \mathrm{Trp}\right), 3.29$ (m, 9H, $\left.\beta-\mathrm{CH}_{2} \operatorname{Trp}\right), 3.51$ (s, 6H, $\left.\mathrm{CH} 2 \mathrm{CO}\right), 4.70$ (m, $9 \mathrm{H}$, $\alpha$-CHTrp), 6.96 (m, 9H, Ar), 7.03 (m, 9H, Ar), 7.08 (s, 9H, Ar) 7.28 (d, J=7.9 Hz, 9H, Ar), 7.55 (d, J = 7.9 Hz, 9H, Ar), 8.17 (s, 9H, NH), 10.29 (bs, 9H, NH-1 1 Trp). ${ }^{13} \mathrm{C}$ NMR (125 MHz, DMSO-d 6$) \delta: 14.18\left(\mathrm{CH}_{3}\right), 22.49\left(\mathrm{CH}_{2}\right), 23.59\left(\mathrm{CH}_{2}\right), 27.57$ $\left(\mathrm{CH}_{2}\right), 29.93\left(\mathrm{CH}_{2}\right), 30.59\left(\mathrm{CH}_{2}\right), 47.24(\mathrm{C}), 54.10(\mathrm{C}), 110.10(\mathrm{C}), 111.45(\mathrm{CH}), 118.35(\mathrm{CH}), 118,81(\mathrm{CH}), 121.41(\mathrm{CH})$, $123.69(\mathrm{CH}), 127.63(\mathrm{C}), 136.89(\mathrm{C}), 174.19(\mathrm{C}=\mathrm{O})$. HPLC [gradient: A:B, 10-100\% of A in $10 \mathrm{~min}$ ]: $8.20 \mathrm{~min}^{\mathrm{HRMS}}(\mathrm{ESI})^{-}$ $m / z$ : Cald. for $\mathrm{C}_{147} \mathrm{H}_{159} \mathrm{~N}_{21} \mathrm{O}_{30} 2698.1562$. Found 2698.1543.

\subsubsection{Dendrimer (5d)}

Following the general procedure for the deprotection of methyl esters, compound 4d (1.00 g, $0.34 \mathrm{mmol})$ gave $46.7 \mathrm{mg}$ (49\%) of $\mathbf{5 d}$ as an amorphous white solid. ${ }^{1} \mathrm{H}$ NMR (500 MHz, DMSO-d 6$) \delta: 1.72\left(\mathrm{~m}, 18 \mathrm{H}, \mathrm{CH}_{2}\right), 2.01\left(\mathrm{~m}, 18 \mathrm{H}, \mathrm{CH}_{2}\right), 2.97(\mathrm{~m}$, $9 \mathrm{H}, \beta-\mathrm{CH}_{2} \mathrm{Trp}$ ), 3.11 (m, 9H, $\beta-\mathrm{CH}_{2}$ Trp), 3.51 (s, 6H, $\mathrm{CH}_{2} \mathrm{NH}$ ), 4.42 (m, 9H, $\left.\alpha-\mathrm{CHTrp}\right), 6.91$ (m, 9H, Ar), 6.98 (m, 9H, Ar), 7.10 (s, 9H, Ar), 7.27 (m, 9H, Ar), 7.50 (m, 9H, Ar), 8.15 (s, 9H, NH), 10.78 (bs, 9H, NH-1 $\left.1^{\mathrm{i} T r p}\right) .{ }^{13} \mathrm{C}$ NMR (125 MHz, DMSO$\left.\mathrm{d}_{6}\right) \delta: 14.40\left(\mathrm{CH}_{2}\right), 29.45\left(\mathrm{CH}_{2}\right), 31.37\left(\mathrm{CH}_{2}\right), 53.72(\mathrm{C}), 63.21\left(\mathrm{CH}_{2}\right), 69.79(\mathrm{CH}), 111.73(\mathrm{CH}), 118.66(\mathrm{CH}), 121.18(\mathrm{CH})$, $123.98(\mathrm{CH}), 127.77(\mathrm{C}), 136.44(\mathrm{C}), 158.36(\mathrm{C}=\mathrm{O}), 172.90(\mathrm{C}=\mathrm{O}), 174.57(\mathrm{C}=\mathrm{O})$. HPLC [gradient: A:B, 10-100\% of A in 10 min]: 8.17 min. HRMS (ESI') $m / z$ : Cald. for $\mathrm{C}_{135} \mathrm{H}_{144} \mathrm{~N}_{22} \mathrm{O}_{30}$ 2553.0419. Found 2553.0437.

\subsubsection{Dendrimer (5f)}

Following the general method for deprotection of methyl esters, compound $\mathbf{4 f}$ (1.56 g, $0.34 \mathrm{mmol})$ gave $352 \mathrm{mg}$ (24\%) of $\mathbf{5 f}$ as an amorphous white solid. ${ }^{1} \mathrm{H}$ NMR $\left(500 \mathrm{MHz}, \mathrm{DMSO}-\mathrm{d}_{6}\right) \delta: 1.75\left(\mathrm{~m}, 30 \mathrm{H}, \mathrm{CH}_{2}\right), 2,05\left(\mathrm{~m}, 38 \mathrm{H}, \mathrm{CH}_{2}\right), 2.99(\mathrm{~m}, 25 \mathrm{H}, \beta$ $\left.\mathrm{CH}_{2} \operatorname{Trp}, \mathrm{CH}_{2} \mathrm{NH}\right), 3.13$ (m, $\left.15 \mathrm{H}, \beta-\mathrm{CH}_{2} \operatorname{Trp}\right), 4.49$ (q, $J=7.7 \mathrm{~Hz}$ and $\left.J=7.1 \mathrm{~Hz}, 15 \mathrm{H}, \alpha-\mathrm{CHTrp}\right), 6.90(\mathrm{t}, J=7.6 \mathrm{~Hz}, 15 \mathrm{H}, \mathrm{Ar})$, 6.97 (t, $J=7.6 \mathrm{~Hz}, 15 \mathrm{H}, \mathrm{Ar}), 7.09$ (s, 15H, Ar), 7.26 (d, J=7.9 Hz, 15H, Ar), 7.48 (d, J=7.9 Hz, 15H, Ar), 8.09 (s, $15 \mathrm{H}, \mathrm{NH})$, 10.72 (bs, 15H, NH-1 ${ }^{\mathrm{i}} \mathrm{Trp}$ ), 12.55 (bs, 15H, COOH). ${ }^{13} \mathrm{C}$ NMR (125 MHz, DMSO-d $)$ ) $8: 27.64\left(\mathrm{CH}_{2}\right), 29.22\left(\mathrm{CH}_{2}\right), 30.53$ $\left(\mathrm{CH}_{2}\right), 53.76\left(\mathrm{CH}_{2}\right), 110,00(\mathrm{CH}), 111.61(\mathrm{CH}), 118.58(\mathrm{CH}), 118.67(\mathrm{CH}), 121.34(\mathrm{CH}), 124.14(\mathrm{CH}), 127.74(\mathrm{C}), 136.73(\mathrm{C})$, $172.76(\mathrm{C}=\mathrm{O}), 176.56(\mathrm{C}=\mathrm{O})$. HPLC [gradient: $\mathrm{A}: \mathrm{B}, 10-100 \%$ of $\mathrm{A}$ in $10 \mathrm{~min}$ ]: $8.83 \mathrm{~min}$. HRMS (ESI) $\mathrm{m} / \mathrm{z}: \mathrm{Cald}^{-}$for $\mathrm{C}_{229} \mathrm{H}_{248} \mathrm{~N}_{38} \mathrm{O}_{50} 4329.8032$. Found 4329.8070 .

\subsubsection{Dendrimer (5g)}

Following the general method for deprotection of methyl esters, compound $\mathbf{4 g}$ (66 mg, $0.012 \mathrm{mmol})$ gave $49 \mathrm{mg}(78 \%)$ of $\mathbf{5 g}$ as an amorphous white solid. ${ }^{1} \mathrm{H}$ NMR $\left(500 \mathrm{MHz}, \mathrm{DMSO}-\mathrm{d}_{6}\right) \delta: 1.50-1.97\left(\mathrm{~m}, 84 \mathrm{H}, \mathrm{CH}_{2}\right), 2.96-3.23\left(\mathrm{~m}, 48 \mathrm{H}, \beta-\mathrm{CH}_{2} \mathrm{Trp}\right.$, $\mathrm{NCH}_{2}$ ), 4.42 (m, 18H, $\alpha$-CHTrp), 6.87-7.47 (m, 90H, Ar, H-2 $\left.\operatorname{Trp}\right), 7.91$ (s, 18H, NH), 10.86 (s, 18H, NH-1 $\left.{ }^{\mathrm{i}} \operatorname{Trp}\right) .{ }^{13} \mathrm{C}$ NMR (125 MHz, DMSO-d $\left.\mathrm{d}_{6}\right)$ : $24.67\left(\mathrm{CH}_{2}\right), 31.88\left(\mathrm{CH}_{2}\right), 31.97\left(\mathrm{CH}_{2}\right), 52.43(\mathrm{C}), 55.89(\mathrm{C}), 78.86\left(\mathrm{CH}_{2}\right), 80.80\left(\mathrm{CH}_{2}\right), 103.03(\mathrm{C})$, $114.94(\mathrm{C}), 118.88(\mathrm{CH}), 122.09(\mathrm{CH}), 127.66(\mathrm{C}), 137.36(\mathrm{C}), 160.59(\mathrm{C}=\mathrm{O}), 173.21(\mathrm{C}=\mathrm{O}), 220.92(\mathrm{C}=\mathrm{O})$. HPLC [gradient: $\mathrm{A}: \mathrm{B}, 10-100 \%$ of $\mathrm{A}$ in $10 \mathrm{~min}$ ]: $9.17 \mathrm{~min}$. HRMS (ESI) $\mathrm{m} / z$ : Cald. for $\mathrm{C}_{276} \mathrm{H}_{300} \mathrm{~N}_{46} \mathrm{O}_{60}$ 5218.1838. Found 5218.1873.

\subsubsection{General Procedure for the deprotection of the benzyl esters $4 \boldsymbol{b}, \boldsymbol{c}, \boldsymbol{e}$}

A solution of the corresponding OBn protected derivative $(1.0 \mathrm{mmol})$ in THF/methanol $(1: 1 ; 20 \mathrm{~mL})$ containing $\mathrm{Pd}(10 \%$ on C; 30 wt.-\%) was hydrogenated at 2.85 atm (42 psi) at $30{ }^{\circ} \mathrm{C}$ overnight. The Pd/C was filtered through Whatman ${ }^{\circledR}$ filter paper 42, washed with methanol and the solvent was removed under reduced pressure to afford the crude deprotected derivative 
which was then purified on a Biotage HPFC system (High Performance Flash Chromatography) on reverse phase using water/acetonitrile (100:0 to 0:100) as eluent.

\subsubsection{Dendrimer (5b)}

Following the general method for deprotection of benzyl esters, compound $\mathbf{4 b}(880 \mathrm{mg}, 0.26 \mathrm{mmol})$ gave $134 \mathrm{mg}(20 \%)$ of 5b as a white amorphous solid. ${ }^{1} \mathrm{H}$ NMR $\left(400 \mathrm{MHz}, \mathrm{CD}_{3} \mathrm{OD}\right) \delta: 1.33\left(\mathrm{~m}, 18 \mathrm{H}, \mathrm{CH}_{2}\right), 2.08\left(\mathrm{~m}, 18 \mathrm{H}, \mathrm{CH}_{2}\right), 3.13(\mathrm{~m}, 9 \mathrm{H}, \beta$ $\mathrm{CH}_{2}$ Trp), 3.32 (m, 9H, $\beta$ - $\mathrm{CH}_{2}$ Trp), 4.53 (m, 9H, $\alpha$-CHTrp), 6.88 (m, 9H, Ar), 6.99 (m, 9H, Ar), 7.15 (m, 9H, Ar), 7.32 (d, J = $8.0 \mathrm{~Hz}, 9 \mathrm{H}, \mathrm{Ar}), 7.49$ (m, 9H, Ar), 8.35 (bs, 3H, NH). ${ }^{13} \mathrm{C}$ NMR (100 MHz, CD $\left.\mathrm{OD}\right) \delta: 13.83\left(\mathrm{CH}_{2}\right), 29.54\left(\mathrm{CH}_{2}\right), 29.66\left(\mathrm{CH}_{2}\right)$, $54.78(\mathrm{CH}), 104.97(\mathrm{C}), 111.57(\mathrm{CH}), 118.57(\mathrm{CH}), 118,86(\mathrm{CH}), 121.41(\mathrm{CH}), 121.44(\mathrm{CH}), 123.68(\mathrm{CH}), 127.98(\mathrm{CH})$, $136.71(\mathrm{C}), 186.66(\mathrm{C}=\mathrm{O}), 199.59(\mathrm{C}=\mathrm{O})$. HPLC [gradient: A:B, 10-100\% of A in $10 \mathrm{~min}$ ]: $8.05 \mathrm{~min}$. HRMS (ESI) $\mathrm{m} / z$ : Cald. for $\mathrm{C}_{138} \mathrm{H}_{141} \mathrm{~N}_{21} \mathrm{O}_{30}$ 2572.0153. Found 2572.0182.

\subsubsection{Dendrimer (5c)}

Following the general method for deprotection of benzyl esters, compound 4c (1.46 g, $0.43 \mathrm{mmol})$ gave $265 \mathrm{mg}(25 \%)$ of 5c as an amorphous white solid. ${ }^{1} \mathrm{H}$ NMR $\left(400 \mathrm{MHz}, \mathrm{CD}_{3} \mathrm{OD}\right) \delta: 1.45\left(\mathrm{~m}, 3 \mathrm{H}, \mathrm{CH}_{2}\right), 1.82\left(\mathrm{~m}, 18 \mathrm{H}, \mathrm{CH}_{2}\right), 2.06\left(\mathrm{~m}, 18 \mathrm{H}, \mathrm{CH}_{2}\right)$, 2.10 (m, 3H, $\mathrm{CH}_{2}$ ), 3.13 (m, 9H, $\beta-\mathrm{CH}_{2} \mathrm{Trp}$ ), 3.25 (m, 9H, $\beta-\mathrm{CH}_{2}$ Trp), 4.09 (m, 3H,CH), 4.61 (m, 9H, $\left.\alpha-\mathrm{CHTrp}\right), 6.99$ (t, $J=7.8$ $\mathrm{Hz}, 9 \mathrm{H}, \mathrm{Ar}), 7.05$ (t, $J=7.3 \mathrm{~Hz}, 9 \mathrm{H}, \mathrm{Ar}), 7.15$ (s, 9H, Ar), 7.32 (d, $J=8.1 \mathrm{~Hz}, 9 \mathrm{H}, \mathrm{Ar}), 7.57$ (d, $J=8.0 \mathrm{~Hz}, 9 \mathrm{H}, \mathrm{Ar}) .{ }^{13} \mathrm{C} \mathrm{NMR}$ (100 MHz, $\left.\mathrm{CD}_{3} \mathrm{OD}\right) \delta$ : $16.74\left(\mathrm{CH}_{2}\right), 29.87\left(\mathrm{CH}_{2}\right), 32.32\left(\mathrm{CH}_{2}\right), 43.95\left(\mathrm{CH}_{2}\right), 45.01(\mathrm{CH}), 54.09(\mathrm{C}), 56.22(\mathrm{CH}), 104.95(\mathrm{C})$, $111.24(\mathrm{CH}), 118.44(\mathrm{CH}), 118,82(\mathrm{CH}), 121.32(\mathrm{CH}), 123.59(\mathrm{CH}), 127.67(\mathrm{C}), 136.83(\mathrm{C}), 176.58(\mathrm{C}=\mathrm{O})$. HPLC [gradient: $\mathrm{A}: \mathrm{B}, 10-100 \%$ of $\mathrm{A}$ in $10 \mathrm{~min}$ ]: $8.07 \mathrm{~min}$. HRMS (ESI) $\mathrm{m} / z$ : Cald. for $\mathrm{C}_{138} \mathrm{H}_{147} \mathrm{~N}_{21} \mathrm{O}_{30}$ 2578.0623. Found 2578.0663.

\subsubsection{Dendrimer (5e)}

Following the general method for deprotection of benzyl esters, compound 4e (345 mg, $0.076 \mathrm{mmol}$ ) gave $162 \mathrm{mg}$ (38\%) of 5e as a white solid; m.p.: 285-287 ${ }^{\circ} \mathrm{C} .{ }^{1} \mathrm{H}$ NMR $\left(500 \mathrm{MHz}, \mathrm{DMSO}-\mathrm{d}_{6}\right) \delta: 1.79\left(\mathrm{~m}, 24 \mathrm{H}, \mathrm{CH}_{2}\right), 2.03\left(\mathrm{~m}, 24 \mathrm{H}, \mathrm{CH}_{2}\right), 2.62(\mathrm{~m}$, $4 \mathrm{H}, \mathrm{CH}_{2}$ ), 2.98 (m, 12H, $\beta$ - $\mathrm{CH}_{2}$ Trp), 3.13 (m, 12H, $\beta-\mathrm{CH}_{2}$ Trp), 3.65 (m, 8H, $\left.C H_{2} \mathrm{NH}\right), 4.47$ (m, 12H, $\left.\alpha-\mathrm{CHTrp}\right), 6.90$ (t, $J=7.3$ $\mathrm{Hz}, 12 \mathrm{H}, \mathrm{Ar}), 6.98$ (t, J = 7.4 Hz, 12H, Ar), 7.10 (s, 12H, Ar), 7.20 (m, 12H, Ar), 7.48 (m, 12H, Ar), 8.12 (s, 12H, NH), 10.73 (bs, 12H, NH-1 $\left.{ }^{\mathrm{i} T r p}\right) .{ }^{13} \mathrm{C}$ NMR (125 MHz, DMSO-d 6$)$ 8: $27.64\left(\mathrm{CH}_{2}\right), 29.84\left(\mathrm{CH}_{2}\right), 30.53\left(\mathrm{CH}_{2}\right), 53.76\left(\mathrm{CH}_{2}\right), 110.34(\mathrm{C})$, $111.77(\mathrm{CH}), 118.63(\mathrm{CH}), 118.79(\mathrm{CH}), 121.27(\mathrm{CH}), 124.04(\mathrm{CH}), 127.66(\mathrm{C}), 136.45(\mathrm{C}), 172.86(\mathrm{C}=\mathrm{O}), 174.12(\mathrm{C}=\mathrm{O})$. HPLC [gradient: A:B, 10-100\% of A in $10 \mathrm{~min}$ ]: $8.99 \mathrm{~min}$. HRMS (ESI) m/z: Cald. for $\mathrm{C}_{182} \mathrm{H}_{196} \mathrm{~N}_{30} \mathrm{O}_{40}$ 3441.4225. Found 3441.423.

\subsubsection{Dendron nitro-nonaTrp $(\mathrm{OMe})(\mathbf{7})$}

A solution of dendron 6 [16] (500 mg, $0.52 \mathrm{mmol})$ and H-(L)-Trp-OMe.HCl (2.08 g, $7.3 \mathrm{mmol})$ in DMF (20 mL) was treated with HATU (2.62 g, $7.3 \mathrm{mmol})$ and DIPEA $(3.7 \mathrm{~mL}, 21.8 \mathrm{mmol})$. The mixture was stirred at room temperature during 3 days and then evaporated to dryness to afford a residue that was dissolved in dichloromethane $(30 \mathrm{~mL})$ and washed successively with aqueous solutions of citric acid $(10 \%)(3 \times 20 \mathrm{~mL})$, saturated $\mathrm{NaHCO}_{3}(3 \times 20 \mathrm{~mL})$, and brine $(3 \times 20 \mathrm{~mL})$. The organic layer was dried over anhydrous $\mathrm{Na}_{2} \mathrm{SO}_{4}$, filtered and evaporated. The residue was purified on a Biotage HPFC system (High Performance Flash Chromatography) on reverse phase using water/acetonitrile (100:0 to 0:100) as eluent to obtain $1.3 \mathrm{~g}$ (91\%) of dendron 7 as a yellow solid; m.p. 210-212 ${ }^{\circ} \mathrm{C} .{ }^{1} \mathrm{H}$ NMR (300 MHz, DMSO-d $\left.\mathrm{d}_{6}\right) \delta: 1.76\left(\mathrm{~m}, 12 \mathrm{H}, \mathrm{CH}_{2}\right), 2.06\left(\mathrm{~m}, 36 \mathrm{H}, \mathrm{CH}_{2}\right)$, 3.07 (m, 18H, $\left.\beta-\mathrm{CH}_{2} \operatorname{Trp}\right), 3.53$ (s, 27H, OCH $\left.{ }_{3}\right), 4.49$ (m, 9H, $\alpha$-CHTrp), 6.96 (t, J=7.4 Hz, 9H, Ar), 7.04 (t, $J=7.4 \mathrm{~Hz}, 9 \mathrm{H}$ Ar), $7.13(\mathrm{~m}, 9 \mathrm{H}, \mathrm{Ar}), 7.32$ (d, $J=7.6 \mathrm{~Hz}, 9 \mathrm{H}, \mathrm{Ar}), 7.47$ (d, $J=7.7 \mathrm{~Hz}, 9 \mathrm{H}, \mathrm{Ar}), 8.27$ (d, $J=7.3 \mathrm{~Hz}, 9 \mathrm{H}, \mathrm{NH}), 10.82(\mathrm{~m}, 9 \mathrm{H}$, 
NH-1 ${ }^{\mathrm{i}}$ Trp). HPLC [gradient: A:B, 10-100\% of A in $10 \mathrm{~min}$ ]: $8.51 \mathrm{~min}$. HRMS (ESI ${ }^{+}$) m/z: Cald. for $\mathrm{C}_{148} \mathrm{H}_{168} \mathrm{~N}_{22} \mathrm{O}_{32} 2765.2195$. Found 2765.2200.

\subsubsection{Dendron nitro-nonaTrp $(\mathrm{OH})(8)$}

To a solution containing the methyl ester derivative dendron 7 (200 mg, $0.07 \mathrm{mmol})$ in THF (10 ml), a solution of $\mathrm{LiOH} \cdot \mathrm{H}_{2} \mathrm{O}$ $(52,86 \mathrm{mg}, 1,26 \mathrm{mmol})$ in water $(10 \mathrm{ml})$ was added, and the mixture was stirred at room temperature during 3 days. Then formic acid was added to reach $\mathrm{pH}=2$, and volatiles were evaporated to dryness. The residue was purified on a Biotage HPFC system (High Performance Flash Chromatography) on reverse phase using water/acetonitrile (100:0 to 0:100) as eluent to afford $80 \mathrm{mg}(42 \%)$ of 8 as a white solid; m.p. $219-221{ }^{\circ} \mathrm{C} .{ }^{1} \mathrm{H}$ NMR $\left(500 \mathrm{MHz}, \mathrm{DMSO}-\mathrm{d}_{6}\right) \delta: 1.72\left(\mathrm{~m}, 12 \mathrm{H}, \mathrm{CH}_{2}\right), 2.00(\mathrm{~m}$, $36 \mathrm{H}, \mathrm{CH}_{2}$ ), 2.97 (m, 9H, $\beta$ - $\mathrm{CH}_{2}$ Trp), 3.13 (m, 9H, $\beta-\mathrm{CH}_{2}$ Trp), 4.43 (m, 9H, $\alpha$-CHTrp), 6.94 (t, $\left.J=7.5 \mathrm{~Hz}, 9 \mathrm{H}, \mathrm{Ar}\right), 7.01(\mathrm{t}, J=$ $7.6 \mathrm{~Hz}, 9 \mathrm{H}, \mathrm{Ar}), 7.10$ (m, 9H, Ar), 7.29 (d, J=7.8 Hz, 9H, Ar), 7.50 (d, J=7.8 Hz, 9H, Ar), 8.08 (m, 9H, NH), 10.80 (s, $9 \mathrm{H}$, $\mathrm{COOH}) .{ }^{13} \mathrm{C}$ NMR (125 MHz, DMSO-d 6$)$ 8: $27.65\left(\mathrm{CH}_{2}\right), 29.78\left(\mathrm{CH}_{2}\right), 30.65\left(\mathrm{CH}_{2}\right), 53.60(\mathrm{C}), 57.01(\mathrm{CH}), 110.40(\mathrm{C}), 111.80$ $(\mathrm{CH}), 118.59(\mathrm{CH}), 118.79(\mathrm{CH}), 121.33(\mathrm{CH}), 124.01(\mathrm{CH}), 127.64(\mathrm{C}), 136.49(\mathrm{C}), 170.52(\mathrm{C}=\mathrm{O}), 172.59(\mathrm{C}=\mathrm{O}), 174.06$ $(\mathrm{C}=\mathrm{O}), 204.53(\mathrm{C}=\mathrm{O})$. HPLC [gradient: A:B, 10-100\% of A in $10 \mathrm{~min}$ ]: $7.96 \mathrm{~min}$. HRMS (ESI') m/z: Cald. for $\mathrm{C}_{139} \mathrm{H}_{150} \mathrm{~N}_{22} \mathrm{O}_{32}$ 2639.0787. Found 2639.0764.

\subsection{General biological methods}

For testing all the compounds were dissolved in dimethyl sulfoxide, stored at $-20^{\circ} \mathrm{C}$, protected from light and further diluted in culture medium prior to use.

\subsubsection{Anti-HIV Activity Assays in CEM and MT-4 cell cultures}

Inhibition of HIV-1( III $_{\mathrm{B}}$ )- and HIV-2(ROD)-induced cytopathicity in CEM cell cultures was measured in $200 \mu 1$-microtiter 96 well plates containing $\sim 3 \times 10^{5} \mathrm{CEM}$ cells $/ \mathrm{ml}$, infected with $100 \mathrm{CCID}_{50}$ of HIV per milliter and containing appropriate dilutions of the test compounds. After $4-5$ days of incubation at $37^{\circ} \mathrm{C}$ in a $\mathrm{CO}_{2}$-controlled humidified atmosphere, $\mathrm{CEM}$ giant (syncytium) cell formation was examined microscopically. The $\mathrm{EC}_{50}$ (50\% effective concentration) was defined as the compound concentration required to inhibit HIV-induced giant cell formation by $50 \%$. Cytostatic activity was examined by counting the number of the CEM cells that were exposed to the different compound concentrations for 3 days by the use of a Coulter Particle Counter ZI (Harpenden Herz, Analis, Ghent, Belgium).

Some of the compounds were also evaluated for their inhibitory activity against HIV-1 infection in MT-4 cell cultures. Briefly, MT-4 cells $\left(1 \times 10^{6}\right.$ cells $\left./ \mathrm{mL}\right)$ were pre-incubated for $30 \mathrm{~min}$ at $37^{\circ} \mathrm{C}$ with the test compounds in a $200 \mu 1-96$-well plate. Next, NL4.3 virus was added at $100 \mathrm{CCID}_{50}$ of the viral stock. The cytopathic effect was scored microscopically 5 days postinfection, and the $50 \%$ effective concentration $\left(\mathrm{EC}_{50}\right)$ values were determined using the MTS/phenazine ethosulfate method.

\subsubsection{Time-of-addition (TOA) experiments}

Time-of-addition experiments were adapted from previously reported methods [20,21]. Briefly, MT-4 cells were infected with HIV-1( $\left.\mathrm{III}_{\mathrm{B}}\right)$ at an m.o.i. of 0.5. Following a 1 hour adsorption period, cells were washed, distributed in a 96-well tray at 100,000 cells per well and incubated at $37^{\circ} \mathrm{C}$. Test compounds were added at different times $(0,1,2,3,4,5,6,7,8,9,24$, and $25 \mathrm{~h}$ ) after infection. Product added at time point $0 \mathrm{~h}$, was present during the start of infection and was washed away after 1 hour. After washing, fresh product was added to maintain viral suppression throughout the rest of the experiment.

HIV-1 production was determined at $31 \mathrm{~h}$ postinfection via a p24 enzyme-linked immunosorbent assay (Perkin Elmer, Brussels, Belgium). AMD3100 was used at $625 \mathrm{nM}$, dextran sulfate at $12.5 \mu \mathrm{M}$, AZT at $3.8 \mu \mathrm{M}$, ritonavir at $554 \mathrm{nM}$, compounds $\mathbf{1 7 b}$ and $\mathbf{1 7 f}$ at $10 \mu \mathrm{M}$. 


\subsubsection{Surface Plasmon Resonance Experiments for evaluation of the binding of the compounds to gp120 and gp41}

Recombinant gp120 protein from the HIV-1 IIIB strain (ImmunoDiagnostics Inc., Woburn, MA) (produced in cell cultures of chinese hamster ovary cell cultures) and recombinant gp41 HIV-1(HxB2) (Acris Antibodies GmbH, Herford, Germany) were covalently immobilized on the carboxymethylated dextran matrix of a CM7 sensor chip in $10 \mathrm{mM}$ sodium acetate, $\mathrm{pH}$ 4.0, using standard amine coupling chemistry up to a final density of respectively 11,241 RUs and 3,836 RUs. All interaction studies were performed at $25{ }^{\circ} \mathrm{C}$ on a Biacore T200 instrument (GE Healthcare, Uppsala, Sweden). The compounds were diluted in HBS-P (10 mM HEPES, $150 \mathrm{mM} \mathrm{NaCl}$ and 0,05\% surfactant P20; $\mathrm{pH}$ 7.4) supplemented with $5 \%$ dimethyl sulfoxide (DMSO, Merck) and $10 \mathrm{mM} \mathrm{Ca}^{2+}$ at a concentration of $50 \mu \mathrm{M}$. Samples were injected for 2 minutes at a flow rate of $30 \mu 1 / \mathrm{min}$ followed by a dissociation phase of 2 minutes. The sensor chip surface was regenerated with an injection of $50 \mathrm{mM} \mathrm{NaOH}$. A reference flow cell was used as a control for non-specific binding and refractive index changes. Several buffer blanks were used for double referencing. A DMSO concentration series was included to eliminate the contribution of DMSO to the measured response.

Binding affinities $\left(\mathrm{K}_{\mathrm{D}}\right)$ were calculated for $\mathbf{5 f}$ using a CM5 sensor chip at which 1450 RUs gp120 and 600 RUs gp41 were immobilized. For this purpose compound concentrations ranging between 0 and $40 \mu \mathrm{M}$ were used and the $\mathrm{K}_{\mathrm{D}}$ value was derived from steady state analysis in the Biacore T200 Evaluation Software 2.0. Following formula was used to calculate the $K_{D}$ value of 5f: $R_{e q}=C \cdot R_{\max } /\left(K_{D}+C\right)$, where $R_{e q}=$ equilibrium binding level; $R_{\max }=$ maximum binding level; $K_{D}=$ equilibrium dissociation constant; $\mathrm{C}=$ concentration of analyte.

\section{Supporting information}

General chemistry and biological procedures as well as copies of representative ${ }^{1} \mathrm{H}$ and ${ }^{13} \mathrm{C}$ NMR spectra are included.

\section{Acknowledgments}

This work has been supported by the Spanish MINECO (project SAF2012-39760-C02), Plan Nacional de Cooperación Público-Privada. Subprograma INNPACTO (project IPT-2012-0213-060000), the Comunidad de Madrid (BIPEDD2-CMS2010/BMD-2457) and by "The Centers of Excellence" of the K.U.Leuven (EF-05/15 and PF-10/18). The Spanish MEC/MINECO are also acknowledged for a grant to E. Rivero-Buceta.

\section{References}

[1] (a) UNAIDS report on the global AIDS epidemic 2013. Published November, 2013. http://www.unaids.org/sites/default/files/en/media/unaids/contentassets/documents/epidemiology/2013/gr2013/UNAI DS_Global_Report_2013_en.pdf (accessed October 8, 2015). (b) K.M. De Cock, H.W. Jaffe, J.W. Curran, The evolving epidemiology of HIV/AIDS, AIDS 2012, 26, 1205e1213.

[2] (a) Volberding, S. G. Deeks, Antiretroviral therapy and management of HIV infection, Lancet, 2010, 376 (9734), 49-62. (b) E. De Clercq, Anti-HIV drugs: 25 compounds approved within 25 years after the discovery of HIV, Int. J. Antimicrob. Agents 2009, 33, 307-320. (c) S.T. Butera, HIV Chemotherapy: A Critical Review, $1^{\text {st }}$ ed.; Caister Academic Press: Norwich, 2005. (d) R.J. Pomerantz, D.L. Horn, Twenty years of therapy for HIV-1 infection. Nat. Med. 2003, 9, 867-873.

[3] (a) A.M. Margolis, H. Heverling, P.A. Pham, A. Stolbach. A Review of the Toxicity of HIV Medications, J. Med. Toxicol., 2014, 10, 26-39. (b) J.C. Gaardbo, H.J. Hartling, , J. Gerstoft, S.D. Nielsen. Incomplete immune recovery in HIV infection: mechanisms, relevance for clinical care, and possible solutions, Clin. Dev. Immunol., 2012, 670957, 1-17. (c) T. Hawkins, Understanding and managing the adverse effects of antiretroviral therapy. Antiviral Res., 2010, 85, 201-209. (d) M.P. 
Dube, F.R. Sattler, Inflammation and complications of HIV disease, J. Infect. Dis. 2010, 201, 1783-1785. (e) P. Rojas, A. Holguín, Drug resistance in the HIV-1-infected paediatric population worldwide: a systematic review. J. Antimicrob. Chemother. 2014, 69, 2032-2042.

[4] (a) G. Kumari, R.K. Singh. Anti-HIV drug development: structural features and limitations of present day drugs and future challenges in the successful HIV/AIDS treatment. Curr. Pharm. Des., 2013, 19, 1767-1783. (b) F. Barré-Sinoussi, A. L. Ross, J.-F. Delfraissy. Past, present and future: 30 years of HIV research, Nat. Rev. Microbiol. 2013, 12, 877-883. (c) C. Flexner HIV drug development: the next 25 years. Nat. Rev. Drug. Discov. 2007, 6, 959-966. (d) C. Tintori, A. Brai, A. L. Fallacara, R. Fazi, S. Schenone, M. Botta. Protein-protein interactions and human cellular cofactors as new targets for HIV therapy, Curr. Opin. Pharmacol., 2014, 18, 1-8.

[5] (a) A.A.Haqqani, J.C. Tilton, Entry inhibitors and their use in the treatment of HIV-1 infection. Antivir. Res. 2013, 98, 158170. (b) M. Hertje, M. Zhou, U. Dietrich, Inhibition of HIV-1 entry: multiple keys to close the door, ChemMedChem 2010, 11, 1825-1835. (c) C.B Wilen, J.C. Tilton, R.W. Doms, Molecular mechanisms of HIV entry. Adv. Exp. Med. Biol. 2012, 726, 223-242. (d) J. C. Tilton, R.W. Doms, Entry inhibitors in the treatment of HIV-1 infection, Antivir. Res. 2010, 85, 91-100. (e) I.P. Singh, S.K. Chauthe, Small molecule HIV entry inhibitors. Part II. Attachment and fusion inhibitors: 2004-2010. Expert. Opin. Ther. Pat., 2011, 21, 399-416. (f) D.R. Kuritzkes, HIV-1 entry inhibitors: an overview, Curr. Opin. HIV AIDS, 2009, 4, 82-87. (g) J.A. Esté, Virus entry as a target for anti-HIV intervention. Curr. Med. Chem. 2003, 10, 1617-1632.

[6] (a) C.V. Fletcher. Enfuvirtide, a new drug for HIV infection. Lancet 2003, 361, 1577-1578. (b) I.G. Williams, Enfuvirtide (Fuzeon): the first fusion inhibitor. Int. J. Clin. Pract. 2003 57, 890-897.

[7] R.M. Gulick, J. Lalezari, J. Goodrich, N. Clumeck, E. DeJesus, A. Horban, J. Nadler, B. Clotet, A. Karlsson, M. Wohlfeiler, J.B. Montana, M. McHale, J. Sullivan, C. Ridgway, S. Felstead, M.W. Dunne, E. van der Ryst, H. Mayer, M.S. Tems, Maraviroc for previously treated patients with R5HIV-1 infection. N. Engl. J. Med. 2008, 359, 1429-1441.

[8] (a) W.C. Greene, Z. Debyser, Y. Ikeda, E.O. Freed, E. Stephens, W. Yonemoto, R.W. Buckheit, J.A. Esté, T. Cihlar, Novel targets for HIV therapy, Antivir. Res. 2008, 80, 251-265. (b) J.A. Esté, T. Cihlar, Current status and challenges of antiretroviral research and therapy, Antivir. Res. 2010, 85, 25-33.

[9] For recent reviews, see: (a) C. Teixeira, J.R.B. Gomes, P. Gomes, F. Maurel, Viral surface glycoproteins, gp120 and gp41, as potential drug targets against HIV-1: brief overview one quarter of a century past the approval of zidovudine, the first anti-retroviral drug, Eur. J. Med. Chem. 2011, 46, 979-992. (b) A. Flores, E. Quesada. Entry inhibitors directed towards glycoprotein gp120: an overview on a promising target for HIV-1 therapy, Curr. Med. Chem., 2013, 20, 751-771. (c) C.A. Didigu, R.W. Doms. Novel approaches to inhibit HIV entry, Viruses 2012, 4, 309-324; (d) K. Qian, S.L. MorrisNatschke, K.H. Lee. HIV entry inhibitors and their potential in HIV therapy, Med. Res. Rev. 2009, 29, 369-393; (e) L. Saha. HIV entry inhibitors: current status, J. Clin. Diagn. Res. 2008, 2, 1119-1125. (f) S. Nawale, S. Neve, V.J. Kadam, M. P. Toraskar, Emerging drug targets for HIV therapy: a review, Int. J. ChemTech. Res. 2010, 2, 1180-1185. (g) M. Caffrey, HIV envelope: challenges and opportunities for development of entry inhibitors, Trends microbiol., 2011, 19, 191-197.

[10] (a) O. Francesconi, C. Nativi, G. Gabrielli, I. De Simone, S. Noppen, J. Balzarini, S. Liekens, S. Roelens, Antiviral Activity of Synthetic Aminopyrrolic Carbohydrate Binding Agents: Targeting the Glycans of Viral gp120 to Inhibit HIV Entry, Chem. Eur. J., 2015, 21, 10089-10093. (b) T. Liu, B. Huang, P. Zhan, E. De Clercq, X. Liu, Discovery of small molecular inhibitors targeting HIV-1 gp120-CD4 interaction drived from BMS-378806, Eur. J. Med. Chem., 2014, 86, 481-490. (c) F. Sironi, M. Malnati, N. Mongelli, P. Cozzi, C. Guzzo, S. Ghezzi, C. Martínez-Romero, A. GarcíaSastre, P. Lusso, D. Jabes, P. Biswas, Characterization of HIV-1 entry inhibitors with broad activity against R5 and X4 viral strains, J. Transl. Med., 2015, 13, 107-122. (d) M. Tiberi, C. Tintori, E.R. Ceresol, R. Fazi, C. Zamperini, P. 
Calandro, L. Franchi, M. Selvaraj, L. Botta, M. Sampaolo, D. Saita, R. Ferrarese, M. Clementi, F. Canducci, M. Bottaa, Antimicrob. Agents Chemother. 2014, 58, 3043-3052. (e) X.-Y. He, L. Lu, J. Qiu, P. Zou, F. Yu, X.-K. Jiang, L. Li, S. Jiang, S. Liu, L. Xie, Small molecule fusion inhibitors: Design, synthesis and biological evaluation of (Z)-3(5-(3-benzyl-4-oxo-2-thioxothiazolidinylidene)methyl)-N-(3-carboxy-4-hydroxy)phenyl-2,5-dimethylpyrroles and related derivatives targeting HIV-1 gp41, Bioorg. Med. Chem., 2013, 21, 7539-7548.

[11] V. Lozano, L. Aguado, B. Hoorelbeke, M. Renders, M.J. Camarasa, D. Schols, J. Balzarini, A. San-Félix, M. J. PérezPérez. Targeting HIV entry through interaction with envelope glycoprotein 120 (gp120): synthesis and antiviral evaluation of 1,3,5-triazines with aromatic amino acids, J. Med. Chem, 2011, 54, 5335-5348.

[12] G.R. Newkome, R.J. Behera, C.N. Moorefield, G.R. Baker, Cascade polymers: syntheses and characterization of onedirectional arborols Based on adamantine, J. Org. Chem 1991, 56, 7162-7167.

[13] B.M. O’Leary, T. Szabo, N. Svenstrup, C. A. Schalley, A. Lützen, M. Schäfer, J. Jr Rebek,. “Flexiball” Toolkit: A Modular Approach to Self-Assembling Capsules. J. Am. Chem. Soc. 2001, 123 (47), 11519-11533.

[14] L. Fernández, M. Calderón, M. Martinelli, M. Strumia, H. Cerecetto, M. González, J.J. Silber, M. Santo, Evaluation of a new dendrimeric structure as prospective drugs carrier for intravenous administration of antichagasic active compounds. $J$. Phys. Org. Chem. 2008, 21, 1079-1085.

[15] T. Zhou, H. Neubert, D. Y. Liu, Z. D. Liu, Y. M. Ma, X. L. Kong, W. Luo, S. Mark, R. C. Hider, Iron Binding Dendrimers: A Novel Approach for the Treatment of Haemochromatosis. J. Med. Chem. 2006, 49, 4171-4182.

[16] (a) C. Ornelas, J. Broichhagen, M. Weck, Strain-promoted alkyne azide cycloaddition for the functionalization of poly(amide)-based dendrons and dendrimers. J. Am. Chem. Soc. 2010, 132, 3923-3931. (b) C. Akpo, E. Weber, J. Reiche, Synthesis, Langmuir and Langmuir-Blodgett film behavior of new dendritic amphiphiles. New J. Chem. 2006, $1820-1833$.

[17] M. Baba, R. Pauwels, J. Balzarini, J. Arnout, J. Desmyter, E. De Clercq. Mechanism of inhibitory effect of dextran sulfate and heparin on replication of human immunodeficiency virus in vitro. Proc. Natl. Acad. Sci. 1988, 85, 6132-6136.

[18] J. Balzarini, K.V. Laethem, D. Daelemans, S. Hatse, A. Bugatti, M. Rusnati, Y. Igarashi, T. Oki, D. Schols, Pradimicin A, a carbohydrate-binding nonpeptidic lead compounds for treatment of infections with viruses with highly glycosylated envelopes, such as human Immunodeficiency virus, J. Virol. 81, 2007, 362-373.

[19] J. Balzarini, A. Holý, J. Jindrich, L. Naesens, R. Snoeck, D. Schols, E. De Clercq, Differential antiherpesvirus and antiretrovirus effects of the $(\mathrm{S})$ and $(\mathrm{R})$ enantiomers of acyclic nucleoside phosphonates: potent and selective in vitro and in vivo antiretrovirus activities of (R)-9-(2-phosphonomethoxypropyl)-2,6-diaminopurine. Antimicrob. Agents Chemother. 1993, 37, 332-338.

[20] R. Pauwels, K. Andries, J. Desmyter, D. Schols, M. J. Kukla, H. J. Breslin, A. Raeymaeckers, J. Van Gelder, R. Woestenborghs, J. Heykants, K. Schellekens, M. A. C. Janssen, E. De Clercq, P.A.J. Janssen, Potent and selective inhibition of HIV-1 replication in vitro by a novel series of TIBO derivatives. Nature 1990, 343, 470-474.

[21] D. Daelemans, R. Pauwels, E. De Clercq, C. Pannecouque, A time-of-drug addition approach to target identification of antiviral compounds. Nat. Protoc. 2011, 6, 925-933.

[22] T. Mizuochi, M.W. Spellman, M. Larkin, J. Solomon, L.J. Basa, T. Feizi, Carbohydrate structures of the human immunodeficiency-virus (HIV) recombinant envelope glycoprotein gp120 produced in Chinese-hamster ovary cells. Biochem J. 1988, 254, 599-603.

\section{LIST OF CAPTIONS}

Fig. 1. Illustration of the structure of the synthesized compounds

Scheme 1. Synthesis of compounds $2 \mathbf{2 a - d}$ and 3a-d. Reagents and conditions: (i) HATU/DIPEA (ii) $\mathrm{HOOCH}, 40^{\circ} \mathrm{C}, 48 \mathrm{~h}$ 
Scheme 2. Synthesis of compounds 4a-d and 5a-d. Reagents and conditions: (i) H-(L)-Trp-OMe.HCl or H-(L)-Trp-OBn.HCl HATU/DIPEA (ii) a) $\mathrm{LiOH}_{2} \mathrm{H}_{2} \mathrm{O}$ (for $\mathbf{4 a}$ and $\mathbf{4 d}$ ) b) $\mathrm{H}_{2}, \mathrm{Pd} / \mathrm{C}$ (for $\mathbf{4 b}$ and $\mathbf{4 c}$ ), $40^{\circ} \mathrm{C}, 48 \mathrm{~h}$.

Scheme 3. Synthesis of compounds 2e-g and 3e-g. Reagents and conditions: (i) HATU/DIPEA (ii) $\mathrm{HOOCH}, 40^{\circ} \mathrm{C}, 48 \mathrm{~h}$

Scheme 4. Synthesis of compounds 4e-g and 5e-g. Reagents and conditions: (i) H-(L)-Trp-OMe.HCl or H-(L)-Trp-OBn.HCl HATU/DIPEA (ii) a) $\mathrm{H}_{2}, \mathrm{Pd} / \mathrm{C}$ (for $\mathbf{4 e}$ ), b) $\mathrm{LiOH}_{\mathrm{H}} \mathrm{O}$ (for $\mathbf{4 f}$ and $\mathbf{4 g}$ )

Scheme 5. Synthesis of compounds 7-9. Reagents and conditions: (i) H-(L)-Trp-OMe.HCl, HATU/DIPEA (ii) a) LiOH. $\mathrm{H}_{2} \mathrm{O}$

Fig. 2. Time of drug-addition experiment in HIV-1-infected MT-4 cell cultures

Fig. 3. Binding amplitudes of test compounds against HIV-1 gp120/gp41

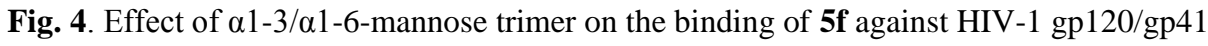

Table 1. Anti-HIV activity of the test compounds

Table 2. Apparent $K_{D}$ value for 5f-gp120 and 5f-gp41 